Proceedings of the Prehistoric Society 87, 2021, pp. 83-107 (C) The Author(s), 2021. Published by Cambridge University Press on behalf of The Prehistoric Society. This is an Open Access article, distributed under the terms of the Creative Commons Attribution licence (http://creativecommons.org/licenses/by/4.0/), which permits unrestricted re-use, distribution, and reproduction in any medium, provided the original work is properly cited. doi:10.1017/ppr.2021.12 First published online 21 September 2021

\title{
Change and Diversity in Neolithic Mortuary Practices on the Isle of Man
}

\author{
By CHRIS FOWLER ${ }^{1}$, RACHEL J. CRELLIN ${ }^{2}$ and MICHELLE GAMBLE ${ }^{3}$
}

While the Early Neolithic chambered tombs of the Isle of Man are well known and the Late Neolithic has been clearly defined with reference to a distinctive suite of artefacts, little is known about the Middle Neolithic. This article reports on 17 new Neolithic radiocarbon dates from cremated human remains from the Isle of Man. These identify five burials in cists as Middle Neolithic and indicate new sequences of activity at cemeteries starting in the Middle Neolithic. Each of these sites is examined in detail. The dates also spur a reconsideration of the development of Ronaldsway pottery and the integration of Grooved Ware pottery and motifs into early 3rd millennium practice on the island. The paper ends with a consideration of the changing effects of mortuary practices throughout the Neolithic on the Isle of Man and a discussion of connections with Middle and Late Neolithic activity in Ireland and Britain.

Keywords: Isle of Man, Middle Neolithic, mortuary practice, radiocarbon dates, Ronaldsway pottery, human remains

Recent decades have seen repeated refinement of our understanding of chronological sequences for the Neolithic in Britain and Ireland (eg. Schulting et al. 2011; Whittle et al. 2011; Bayliss et al. 2017). ${ }^{1}$ This has assisted in the recognition of a Middle Neolithic period following the abandonment of rectangular houses in Ireland, southern Britain, and parts of mainland Scotland, and the cessation of construction of chambered tombs in most of mainland Britain. Regional developments in mortuary practices and monuments during this period (c. 3500/3400-3000 cal BC) include the emergence of passage tombs in parts of Ireland, Anglesey, and Orkney, with related structures in some parts of northern and western Scotland, burial of the dead in Linkardstown cists, rock-cut pits or rock fissures in parts of Ireland, burial in pits in Wales, burials in

\footnotetext{
${ }^{1}$ School of History, Classics \& Archaeology, University of Newcastle Upon Tyne, Armstrong Building, Newcastle Upon Tyne, NE1 7RU Email: chris.fowler@newcastle.ac.uk ${ }^{2}$ Dept of Archaeology and Ancient History, University of Leicester, University Road, Leicester LE1 7RH Email: rjc65@le.ac.uk

${ }^{3}$ Heritage \& Archaeological Research Practice, 101 Rose Street South Lane, Edinburgh EH2 3JG Email: michelle@ harparchaeology.co.uk
}

shafts or pits in parts of Yorkshire, and cemeteries of cremated remains in mainland Britain (eg, Brindley \& Lanting 1989-90; Gibson \& Bayliss 2009; Tellier 2018; Willis 2019). Yet little to nothing has been said about the same period on the Isle of Man.

This article fills the gap between the Early and Late Neolithic on the Isle of Man and thereby provides a more detailed understanding of the sequences of changing mortuary practices in the mid- to late 4th millennium. It discusses the implications of 17 new Neolithic radiocarbon dates from cremated human remains from the Isle of Man obtained as part of the Round Mounds of the Isle of Man Project, which has been re-assessing the evidence for mortuary practices and monuments from the Neolithic and Early Bronze Age on the island since 2016. Funded by Manx National Heritage and Culture Vannin, the project is primarily centred around Early Bronze Age round mounds, on which we have conducted new surveys, landscape analyses, and an excavation (Crellin \& Fowler 2017; 2018; 2020), but has also involved study of the archived material from excavated sites, and an osteological re-analysis of all of the museum holdings of prehistoric human remains (the latter carried out by Michelle Gamble). Drawing on that research, this 


\section{Fowler et al. CHANGE \& DIVERSITY, NEOLITHIC MORTUARY PRACTICES, ISLE OF MAN}

article presents evidence for several contemporary mortuary practices at different kinds of site during the Middle Neolithic. This includes earlier evidence for the deposition of Ronaldsway Jar pottery than previously thought and the Middle Neolithic use of cists which were previously suspected to date to the Early Bronze Age. The article argues that the use of Ronaldsway pottery changed towards the end of the 4th millennium and considers the integration of Grooved Ware pottery and motifs into early 3rd millennium practice on the island. After considering the changing effects of mortuary practices throughout the Neolithic on the Isle of Man, we set these findings alongside contemporaneous burial practices in Britain and Ireland and consider what the material from the Isle of Man adds to a wider understanding of the Middle to Late Neolithic in these regions.

\section{EARLY AND LATE NEOLITHIC ACTIVITY ON THE ISLE OF MAN: PRIOR UNDERSTANDINGS}

Since the early 20th century the Neolithic of the Isle of Man has been described in two distinct halves. The earlier Neolithic has been characterised by carinated or shouldered bowl pottery, leaf-shaped arrowheads, and chambered tombs. Traces of both cremated and unburnt remains have been found within excavated chambers (Lynch 2017, 110). There have been no substantial excavations at a chambered tomb on the Isle of Man for almost 40 years and there are no radiocarbon dates for tomb construction. Charcoal from a hearth set in the forecourt at King Orry's Grave North-East is dated to 3361-2926 cal BC (GU-2693; Table 1), but this seems likely to be late in the history of the tomb. The chambers contained plain bowl pottery, probably from carinated bowls (Burrow 2017), while excavated tombs at Ballaharra, Cashtal yn Ard and Meayll Hill yielded carinated or shouldered bowls (Henshall 2017a, 96-8). Typologically, King Orry's Grave and Cashtal yn Ard are similar to court tombs in Ireland and Clyde tombs in western Scotland. While the few previous dates from Clyde tombs have done little more than indicate an Early to Middle Neolithic use (Noble 2006, 108), recent work has improved the picture. The tomb at Clachaig, Arran, shares a similar chamber arrangement to those on the Isle of Man, albeit with only two such surviving chambers: it includes human remains recently dated to 3517-3362 cal BC (Brace et al. 2019). Excavations at the Clyde tomb at Cladh Aindreis, Argyll, recovered cremated human remains, dated to 3783-3656 cal $\mathrm{BC}$ and thought to be the primary deposit, underneath a round cairn containing a single chamber (Harris et al. 2014, 6; Harris pers. comm.). Bundles of cremated remains from within the chamber provided dates within the period c. 3656-3511 cal BC (ibid.). The round cairn was later incorporated into a long cairn blocking off access to the chamber.

A similar sequence was observed at Blasthill, Argyll, where the first phase of activity in one of the chambers dates to 4040-3710 cal BC with a second phase dated to 3630-3360 cal BC (Cummings \& Robinson 2015, 9-12). The chamber arrangements at these two sites are, however, unlike the chains of chambers found at Cashtal yn Ard (Fig. 1) and King Orry's Graves. Bayesian modelling of radiocarbon dates from court tombs in Ireland, which are more similar to the examples from the Isle of Man, suggests these were built between c. 3700 and 3570 cal BC (Schulting et al. 2011), a little later than Bayesian modelled dates from Clyde cairns (Sheridan \& Schulting 2020, 201, 2034). However, the tombs in the model for Ireland with chamber arrangements and forecourts most similar to Cashtal yn Ard and King Orry's Graves (ie, Aghanaglack, Audleystown, and Annaghmare) only yielded one Neolithic date from human remains within the chamber. This date, from Annaghmare, was Middle Neolithic (3486-3103 cal BC, UB-6741) and Schulting et al. $(2011,10)$ interpret it as derived from a secondary use of the chamber.

While some authors describe the chambered tombs on the Isle of Man as Middle Neolithic (while using an earlier start date for the Middle Neolithic: eg, Burrow 1997), it seems most likely on comparative grounds that the court tombs were first constructed in the Early Neolithic, although it is possible they were modified and/or used into the Middle Neolithic. While Meayll Hill, ${ }^{2}$ Giant's Grave, Kew, Ballaterson Cronk, and Corvalley have sometimes been interpreted as early passage tombs (eg, Darvill 2000), the evidence is currently inconclusive. Meayll Hill contains Early Neolithic shouldered bowl pottery and is typologically unique, but consistent with a broader early to mid-4th millennium tradition of articulating small chambers in different arrangements across western Britain and parts of Ireland. The denuded remains of Giant's Grave, Kew, are diagnostically inconclusive 
TABLE 1. RADIOCARBON DETERMINATIONS FROM NEOLITHIC FEATURES ON THE ISLE OF MAN. THOSE NEWLY REPORTED IN THIS ARTICLE ARE MARKED WITH AN ASTERIX; ALL DATES ARE CALIBRATED USING OXCAL 4.4.2 (BRONK RAMSEY 2009; R:5 ATMOSPHERIC DATA FROM REIMER et al. 2020)

\begin{tabular}{|c|c|c|c|c|c|c|}
\hline Site name & $\begin{array}{c}\text { MNH } \\
\text { NMHER }\end{array}$ & Feature & Material dated & Lab. code & $\begin{array}{l}\text { Determination } \\
B P\end{array}$ & $\begin{array}{c}\text { Calibrated date BC }(95.4 \% \\
\text { probability) }\end{array}$ \\
\hline *Ballafayle & 1078 & Burial & Cremated human bone & $\mathrm{OxA}-36420$ & $5138 \pm 31$ & $4040-3804$ \\
\hline Port St Mary & 0097 & $\begin{array}{l}\text { Red earth from under } \\
\text { cist }\end{array}$ & Charcoal & OxA-2481 & $4970 \pm 80$ & $3953-3638$ \\
\hline$*$ Ballateare & 1355 & Burial - C XIV & Cremated human bone & OxA-36424 & $4786 \pm 29$ & $3638-3525$ \\
\hline *Ballateare & 1355 & Burial - C IV & Cremated human bone & OxA-36422 & $4718 \pm 32$ & $3629-3374$ \\
\hline *Cronk y Voddee & 1716 & Burial - Cist & Cremated human bone & $\mathrm{OxA}-37080$ & $4666 \pm 34$ & $3522-3367$ \\
\hline *Ballateare & 1355 & Burial - C I & Cremated human bone & $\mathrm{OxA}-36421$ & $4656 \pm 32$ & $3516-3367$ \\
\hline *Killeaba & 0231 & Burial - Cremation X & Cremated human bone & OxA-36493 & $4645 \pm 29$ & $3516-3362$ \\
\hline $\begin{array}{l}\text { * West Kimmeragh Boulder } \\
\text { Cist }\end{array}$ & 0397 & Burial - Cist & Cremated human bone & OxA-36598 & $4625 \pm 32$ & $3516-3349$ \\
\hline *Killeaba & 0231 & $\begin{array}{l}\text { Burial - Cremation } \\
\text { VII }\end{array}$ & Cremated human bone & OxA-36492 & $4672 \pm 29$ & $3520-3371$ \\
\hline *Killeaba & 0231 & Burial - Cremation I & Cremated human bone & OxA-36490 & $4574 \pm 30$ & $3494-3105$ \\
\hline *Killeaba & 0231 & Burial - Cremation II & Cremated human bone & $\mathrm{OxA}-36491$ & $4552 \pm 31$ & $3482-3102$ \\
\hline *Ballateare & 1355 & Burial - C XV & Cremated human bone & OxA-36470 & $4546 \pm 30$ & $3370-3102$ \\
\hline *Ballateare & 1355 & Burial - C IX & Cremated human bone & OxA-36423 & $4521 \pm 30$ & $3360-3101$ \\
\hline Killeaba & 0231 & Burial - Cremation III & Cremated human bone & $\mathrm{OxA}-27112$ & $4503 \pm 33$ & $3356-3094$ \\
\hline $\begin{array}{l}\text { Bishop's Demesne, Magher } \\
\text { Y Clagh }\end{array}$ & 1388 & Burial - Cremation & Cremated human bone & OxA-27190 & $4496 \pm 33$ & $3354-3040$ \\
\hline *Cronk Coar & 0430 & Burial - cist & Cremated human bone & OxA-36488 & $4489 \pm 31$ & $3347-3036$ \\
\hline $\begin{array}{l}\text { King Orry's Grave North } \\
\text { East }\end{array}$ & 1071 & $\begin{array}{l}\text { Burnt area in tomb } \\
\text { forecourt }\end{array}$ & Charcoal & GU-2693 & $4470 \pm 80$ & $3361-2926$ \\
\hline Ballacottier & 0320 & Occupation debris & $\begin{array}{l}\text { Carbon on } \\
\text { Ronaldsway sherd }\end{array}$ & OxA-5887 & $4415 \pm 55$ & $3333-2911$ \\
\hline Killeaba & 0231 & $\begin{array}{l}\text { Burial - Timberlined } \\
\text { Pit I }\end{array}$ & $\begin{array}{l}\text { Wood from } \\
\text { Timberlined Pit I }\end{array}$ & BM-839 & $4381 \pm 58$ & $3329-2893$ \\
\hline *West Kimmeragh & 0397 & Burial - cremation & Cremated human bone & OxA-36599 & $4385 \pm 31$ & $3095-2912$ \\
\hline Killeaba & 0231 & $\begin{array}{l}\text { Burial - Timberlined } \\
\text { Pit II }\end{array}$ & $\begin{array}{l}\text { Wood from } \\
\text { Timberlined pit II }\end{array}$ & BM-840 & $4300 \pm 52$ & $3092-2705$ \\
\hline *Ramsey & NA & Burial - cremation & Cremated human bone & OxA-36595 & $4358 \pm 30$ & $3084-2902$ \\
\hline West Kimmeragh & 0397 & Cobbled surface, pits & $\begin{array}{l}\text { Carbon on } \\
\text { Ronaldsway sherd }\end{array}$ & OxA-5890 & $4255 \pm 70$ & $3081-2624$ \\
\hline West Kimmeragh & 0397 & Cobbled surface, pits & $\begin{array}{l}\text { Carbon on } \\
\text { Ronaldsway sherd }\end{array}$ & OxA-5891 & $4280 \pm 50$ & $3078-2697$ \\
\hline *Ballavarry & 0327 & Burial - cremation & Cremated human bone & OxA-36487 & $4347 \pm 29$ & $3076-2898$ \\
\hline West Kimmeragh & 0397 & Cobbled surface, pits & $\begin{array}{l}\text { Carbon on } \\
\text { Ronaldsway sherd }\end{array}$ & OxA-5889 & $4260 \pm 50$ & $3014-2674$ \\
\hline Ballaharra & 0962 & Burial - Cremation I & Charcoal in cremation I & BM-769 & $4233 \pm 59$ & $3009-2623$ \\
\hline Ballateare & 1355 & Burial - pottery sherd & $\begin{array}{l}\text { Carbon on } \\
\text { Ronaldsway sherd }\end{array}$ & OxA-5885 & $4240 \pm 55$ & $3008-2629$ \\
\hline
\end{tabular}


TABLE 1. (Continued)

\begin{tabular}{|c|c|c|c|c|c|c|}
\hline Site name & $\begin{array}{c}\text { MNH } \\
\text { NMHER } \\
\end{array}$ & Feature & Material dated & Lab. code & $\begin{array}{c}\text { Determination } \\
B P \\
\end{array}$ & $\begin{array}{c}\text { Calibrated date BC }(95.4 \% \\
\text { probability) }\end{array}$ \\
\hline Ballaharra & 0962 & Burial - Cremation I & $\begin{array}{l}\text { Charcoal in cremation } \\
\text { I }\end{array}$ & BM-768 & $4225 \pm 67$ & $3008-2580$ \\
\hline Ballavarry & 0327 & $\begin{array}{l}\text { Pit site with human } \\
\text { remains }\end{array}$ & $\begin{array}{l}\text { Carbon on } \\
\text { Ronaldsway sherd }\end{array}$ & OxA-5332 & $4185 \pm 55$ & $2900-2584$ \\
\hline Ballateare & 1355 & Cremation VII & Cremated human bone & OxA-27189 & $4172 \pm 33$ & $2885-2631$ \\
\hline Ballavarry & 0327 & $\begin{array}{l}\text { Pit site with human } \\
\text { remains }\end{array}$ & Charcoal & GU-2696 & $4140 \pm 50$ & $2879-2579$ \\
\hline Ballalheaney & 0332 & Occupation debris & $\begin{array}{l}\text { Carbon on } \\
\text { Ronaldsway sherd }\end{array}$ & OxA-5892 & $4075 \pm 50$ & $2866-2473$ \\
\hline Ronaldsway 'House' & 0106 & Occupation site & $\begin{array}{l}\text { Carbon on } \\
\text { Ronaldsway sherd }\end{array}$ & OxA-5330 & $4010 \pm 55$ & $2848-2346$ \\
\hline Ballavarry & 0327 & $\begin{array}{l}\text { Pit site with human } \\
\text { remains }\end{array}$ & Charcoal & OxA-5331 & $4035 \pm 40$ & $2841-2465$ \\
\hline Ballateare & 1355 & Burial - cremation & $\begin{array}{l}\text { Carbon on } \\
\text { Ronaldsway sherd }\end{array}$ & OxA-5884 & $3955 \pm 70$ & $2832-2822$ \\
\hline Ballalheaney & 0332 & Occupation debris & $\begin{array}{l}\text { Carbon on } \\
\text { Ronaldsway sherd }\end{array}$ & OxA-5893 & $3980 \pm 55$ & $2663-2295$ \\
\hline Glencrutchery & 0250 & Occupation debris & $\begin{array}{l}\text { Carbon on } \\
\text { Ronaldsway sherd }\end{array}$ & OxA-5427 & $3950 \pm 55$ & $2618-2235$ \\
\hline Ronaldsway House & 0106 & Occupation site & $\begin{array}{l}\text { Carbon on } \\
\text { Ronaldsway sherd }\end{array}$ & OxA-5329 & $3985 \pm 35$ & 2617-2351 \\
\hline Ballacottier & 0320 & Occupation debris & $\begin{array}{l}\text { Carbon on } \\
\text { Ronaldsway sherd }\end{array}$ & OxA-5888 & $3945 \pm 50$ & $2575-2290$ \\
\hline Glencrutchery & 0250 & Occupation debris & $\begin{array}{l}\text { Carbon on } \\
\text { Ronaldsway sherd }\end{array}$ & OxA-5335 & $3930 \pm 40$ & $2567-2292$ \\
\hline Ronaldsway House & 0106 & Occupation site & $\begin{array}{l}\text { Carbon on } \\
\text { Ronaldsway sherd }\end{array}$ & OxA-5328 & $3925 \pm 35$ & $2560-2539$ \\
\hline Glencrutchery & 0250 & Occupation debris & $\begin{array}{l}\text { Carbon on } \\
\text { Ronaldsway sherd }\end{array}$ & OxA-5334 & $3915 \pm 35$ & $2557-2289$ \\
\hline Ballavarry & 0327 & $\begin{array}{l}\text { Pit site with human } \\
\text { remains }\end{array}$ & $\begin{array}{l}\text { Carbon on } \\
\text { Ronaldsway sherd }\end{array}$ & OxA-5333 & $3830 \pm 80$ & $2476-2034$ \\
\hline *Strandhall & 0057 & $\begin{array}{l}\text { Burial - Cremation } \\
\text { burial }\end{array}$ & Cremated human bone & OxA-36596 & $3859 \pm 29$ & 2459-2206 \\
\hline Ballacottier & 0320 & Occupation debris & $\begin{array}{l}\text { Carbon on } \\
\text { Ronaldsway sherd }\end{array}$ & OxA-5886 & $3790 \pm 50$ & $2452-2039$ \\
\hline
\end{tabular}




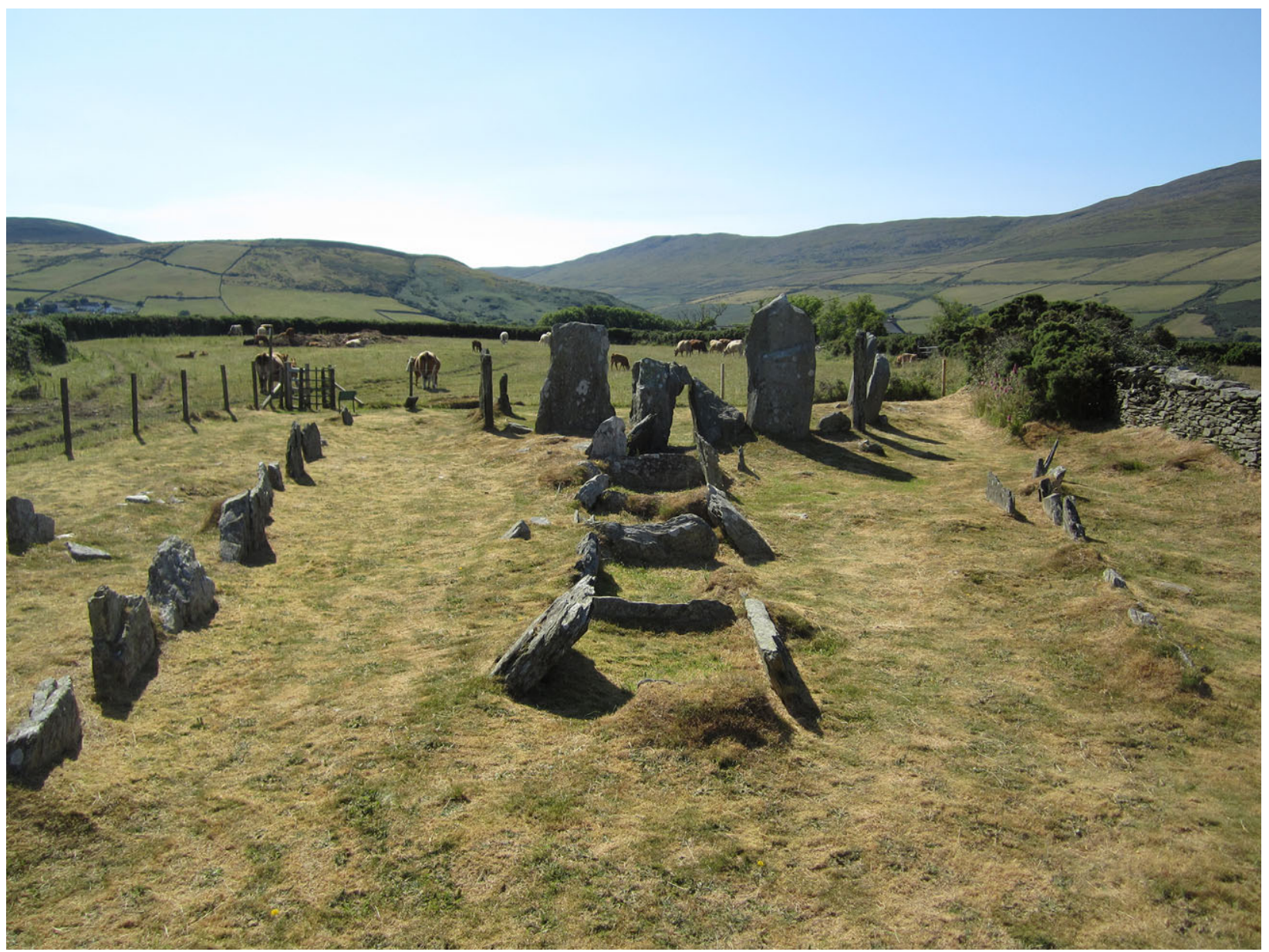

Fig. 1.

Chambered tomb at Cashtal yn Ard photographed from the rear (photograph: Chris Fowler)

and undated. Corvalley is unexcavated, has a small box chamber, and shows no indication of a passage. Ballaterson Cronk was excavated in the 1900s (Harrison 1909) leaving sparse records and while it may be a passage grave it could also be interpreted as a habitation site (MNH NMHER 0522).

Grooved Ware pottery, small square houses with circular exteriors, the deposition of cremated remains, timber and stone circles, and henge monuments feature heavily in accounts of Late Neolithic Britain (eg, Thomas 2010; Cummings 2017, 166-233). Monument complexes, including those incorporating passage tombs (eg, Cooney 2000, 127-73; Cummings 2017, 210-12), and circular houses (Smyth 2014), are well represented in discussions of Late Neolithic Ireland. Henges, passage tombs and/ or houses are currently rare or absent from some regions of Britain and Ireland, however, and there is diversity in house form, occupation practice, subsistence, and mortuary practices in some regions. Other than a $1.8 \mathrm{~m}$ diameter annular ditch with two opposed causeways termed a 'mini-henge' by Darvill (2000, 380), who describes it as 'perfect in every respect with a pair of aligned entrances and internal pits containing burnt bone and quartz pebbles', there are no henges on the Isle of Man. The Island features some locally-distinctive forms of Late Neolithic material culture including hump-backed scrapers, Ronaldsway Jar pottery, roughened/truncated butt axeheads (RTBs), and schist or slate plaques, some of which are incised with Grooved Ware-style motifs (Burrow 1997). Sherds of 


\section{Fowler et al. CHANGE \& DIVERSITY, NEOLITHIC MORTUARY PRACTICES, ISLE OF MAN}
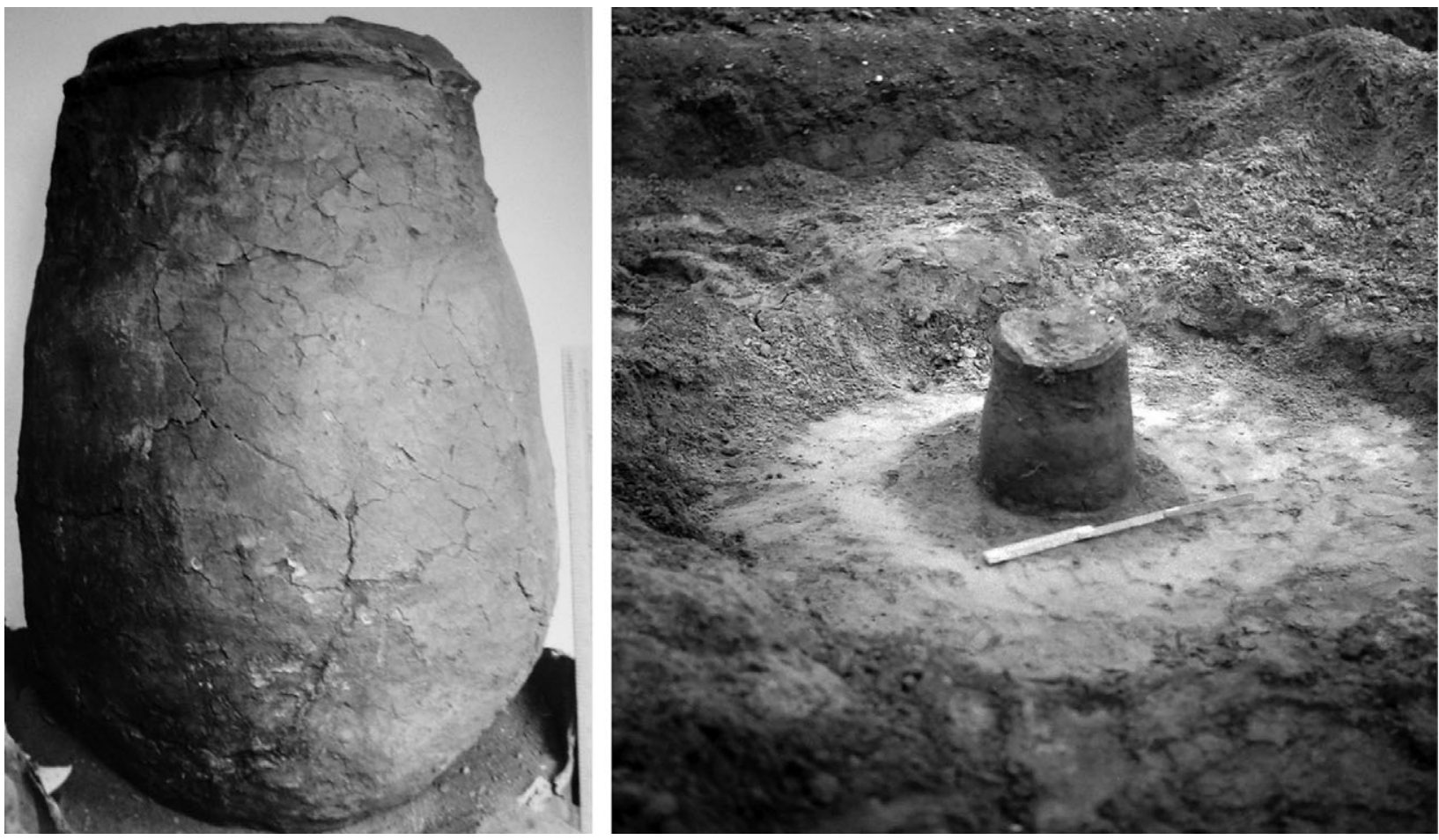

Fig. 2.

Earthfast Jar CX from Ballateare. Left: complete vessel after excavation; right: vessel in situ with cut and fill visible (photographs from the Manx Museum, with kind permission of the trustees of Manx National Heritage)

Grooved Ware have been found at a few sites, always in association with Ronaldsway Jar pottery and other Late Neolithic artefacts: Glencrutchery (Bruce et al. 1947; Burrow 1997); Ballacottier (Garrad 1984a), and the Ronaldsway 'house' (Bruce et al. 1947). Ronaldsway Jar pottery is a baggy, thick-walled coarseware and jars are often found in deep, narrow pits in which some of them sit very snuggly; they are therefore referred to as earthfast jars (Fig. 2). Impressed or incised decoration is often found on the rims of Ronaldsway vessels. Darvill and Andrews (2014) have identified polychrome paint on the exterior of an earthfast jar from Billown which they interpret as depicting a sinuous horizon dividing earth from sky. ${ }^{3}$

Following excavation at Ronaldsway airport in 1946, Bruce et al. (1947) identified a Late Neolithic Ronaldsway 'culture' with this suite of material culture and rectangular houses. The same year Bersu (1947) suggested that a cemetery at Ballateare, which included earthfast jars and deposits of cremated remains, should be seen as the type cemetery for this 'Ronaldsway Culture'. Based on these assessments, the Ronaldsway Culture became one of Piggott's (1954) secondary Neolithic cultures. The Ronaldsway 'house' is a complex key-hole shaped site, excavated in difficult circumstances during World War II. It contained fragments of Grooved Ware and slate plaques, two of which are incised with diamond motifs, and Ronaldsway Jar pottery. The site challenges easy interpretation (Crellin 2014; 2019, 46), and since no further such structures have been found in the last 80 years, despite the discovery of numerous sites with Ronaldsway pottery, we do not think such buildings can be seen as a defining characteristic of a Ronaldsway Culture. ${ }^{4}$ We also reject the term 'Ronaldsway Culture' as it smuggles in some weighty culture-historic baggage about the boundedness and unity of cultural groups.

Hump-backed scrapers, Ronaldsway Jar pottery, RTB axeheads, and schist or slate plaques do seem to be distinctive forms of artefacts produced locally. However, while many RTB axes are made from a local rock source, Group XXV, some seem to have been modified from axeheads deriving from various 


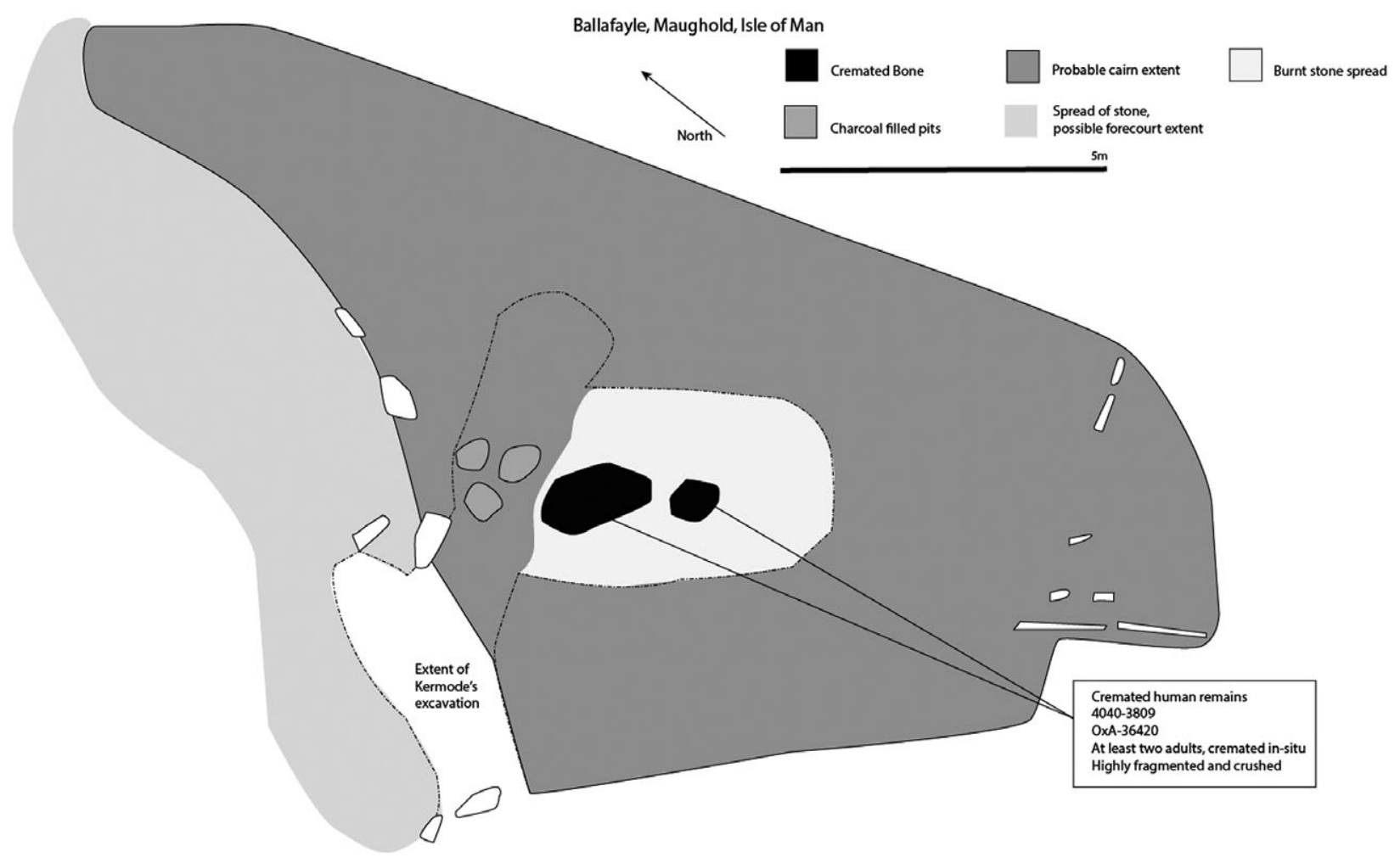

Fig. 3.

Plan of Ballafayle (source: Henshall 2017b, 45; redrawn by R.J. Crellin)

sources, including Group IX (Antrim), Group VI (Langdale), Group VII (north Wales), and Group I (Cornwall) (Barrs 2010, 36; Kewley 2016, 135, 144). This suggests either continuing contact with other regions or the deposition of axes with older origins. RTB axeheads have also been found in south-west Scotland, Ireland, Yorkshire, and Hampshire (Barrs 2010, 41), again suggesting ongoing cultural interaction (cf. Crellin 2014). Radiocarbon dates obtained by previous projects have generally returned results associated with Ronaldsway pottery between $3100 \mathrm{BC}$ and 2400/ $2300 \mathrm{cal} \mathrm{BC}$; eight of these dates derive from charcoal and 17 from carbonised residues on ceramic sherds (Burrow \& Darvill 1997; Table 1).

The link between the Early and Late Neolithic is poorly understood, it is unclear when the Late Neolithic material traditions originated and the dates available prior to our project left a significant gap between the supposed abandonment of chambered tombs, somewhere in the middle 4th millennium, and the earliest Late Neolithic Ronaldsway material.

\section{AN EARLY NEOLITHIC CREMATORIUM AT BALLAFAYLE}

The earliest date from the human remains sampled comes from an Early Neolithic trapezoidal cairn at Ballafayle (Fig. 3). The date of 4040-3804 cal BC (OxA-36420; Table 1) falls within the range of a less precise date of 4055-3641 cal BC (I-6409, 5070 \pm 105 BP calibrated at $93.7 \%$ probability) from a similar monument at Lochhill in Dumfries \& Galloway (Masters 1973). Both the excavator and Gamble's osteological analysis indicate that a burning wood, earth and stone structure collapsed down on top of the remains of two adults: some bones were still articulated, many were highly fragmented and crushed, and the blaze was not hot enough to fully calcine the long bones (Gamble 2017a; Appendix S.1). In this case the remains of the dead were contained within and covered by the mound; they do not seem to have 


\section{Fowler et al. CHANGE \& DIVERSITY, NEOLITHIC MORTUARY PRACTICES, ISLE OF MAN}

been accessible following the fire. This contrasts with human remains placed in the megalithic chambered tombs on the island which provided access to at least one chamber at the tomb entrance and possibly more if the means of access was via the roof to the chambers (cf. Fowler 2004; 2008).

No human remains recovered from chambered tombs on the island that we expect were constructed in the Early Neolithic are available for dating in the Manx Museum, although the presence of both Early and Middle Neolithic human remains from tombs in neighbouring regions is suggestive of periods of tomb alteration and/or re-use (eg, at Annaghmare, as discussed above). We therefore suggest a shift in practice from the relatively rapid sealing off of human remains from access through a dramatic conflagration at Ballafayle to the provision of future access to the remains of the dead at chambered tombs.

\section{DIVERSITY IN MIDDLE NEOLITHIC MORTUARY PRACTICES}

Twelve new dates on cremated bone from the late Early Neolithic or Middle Neolithic significantly increase our understanding of funerary activity from this period (Table 1; Fig. 4; see Appendix S.1 for osteological details). ${ }^{5}$ Five of these dates were obtained from cremated remains buried within cists. A cist excavated in 1965 at Cronk y Voddee (or Voddey) contained cremated remains that were originally identified as the remains of an inhumation. While the bones show little of the transverse checking or longitudinal splitting usually resulting from cremation, they are cracked and white. There is little information about this cist in the Manx National Heritage archive, but it was $c .0 .75 \mathrm{~m}$ square and contained no artefacts. The remains constitute less than $1 \%$ of the skeleton of an adult (Gamble 2017b; Appendix S.1) and have now been dated to 3522-3367 cal BC (OxA-37080; Table 1).

A cist at West Kimmeragh, Bride, was coined the 'boulder cist' by its excavator, Larch Garrad (Garrad 1987; Fig. 5). It was discovered when the cover slab was displaced during ploughing - there was no trace of a mound and the cist sat in a pit cut into the earth. It lies $12 \mathrm{~m}$ away from a cobbled surface and cluster of Late Neolithic pits containing Ronaldsway pottery (Garrad 1987, 426; note that this site is also referred to as West Kimmeragh). Although the excavator reported that the boulder cist contained an inhumation the bones investigated by Gamble (2017c; Appendix S.1) were all cremated. The bone fragments are quite large, which may explain why they were mistaken for inhumed remains (Fig. 6). They constitute about $65 \%$ of a single child's skeleton, around 6-10 years old at death, and the date obtained was very similar to that from Cronk y Voddee: 3516 3349 cal BC (OxA-36598; Table 1). Gamble's examination of the human remains also recovered a tiny stone disc bead. Disc beads have been found at roughly contemporaneous sites in Ireland, such as the passage tomb at Tomb of the Hostages (O'Sullivan 2005), though it is risky to infer too much from one bead.

A cist at Bishop's Demesne previously returned a Middle Neolithic date of 3354-3040 cal вС (OxA27190; Table 1; cf. Crellin 2014). This small slate cist was excavated by Larch Garrad in 1987. There are only brief notes in the archive (MNH NMHER 1388), which read: 'Cist $0.7 \times .3 \times .6$ deep with 3 4 layers of small stones piled over and traces of stony mound with $2 \mathrm{~m}$ wide peripheral ditch found to $\mathrm{N}$. c. $10 \mathrm{~m}$ diam of circle complete', and: 'Skull, top down with articulated lower jaw in compact mass of cremation. No obvious signs of container. No small finds.' We have been unable to find any images of the cist or any further details. In contrast to Cronk y Voddee, $85 \%$ of the cremated skeleton of one small individual was present at Bishops Demesne: this was either a female adult or an older adolescent (Gamble 2017d; Appendix S.1; Fig. 7).

Finally, at Cronk Coar, Ballaugh, cremated human remains from a cist on the summit of a low natural mound excavated by A.M. Cubbon in 1977 provided a date of 3347-3036 cal BC (OxA-36488; Table 1). Only a small amount of cremated bone was recovered from the cist (with $55.8 \mathrm{~g}$ surviving in the museum) and, while age, sex and MNI are inconclusive, the cortical bone thickness of various fragments suggest at least one adult and one child (Gamble 2017e; Appendix S.1). The cist contained no artefacts although both Ronaldsway and Early Bronze Age pottery has been recovered from the field, as have other cremated bones. A 5th Middle Neolithic cist was located among a cemetery of cremation deposits at Killeaba, discussed below.

The remains in these five cists therefore date to the Middle Neolithic. ${ }^{6}$ Prior to their radiocarbon dating these cists were assumed to date from the Early Bronze Age, underscoring the importance of obtaining 


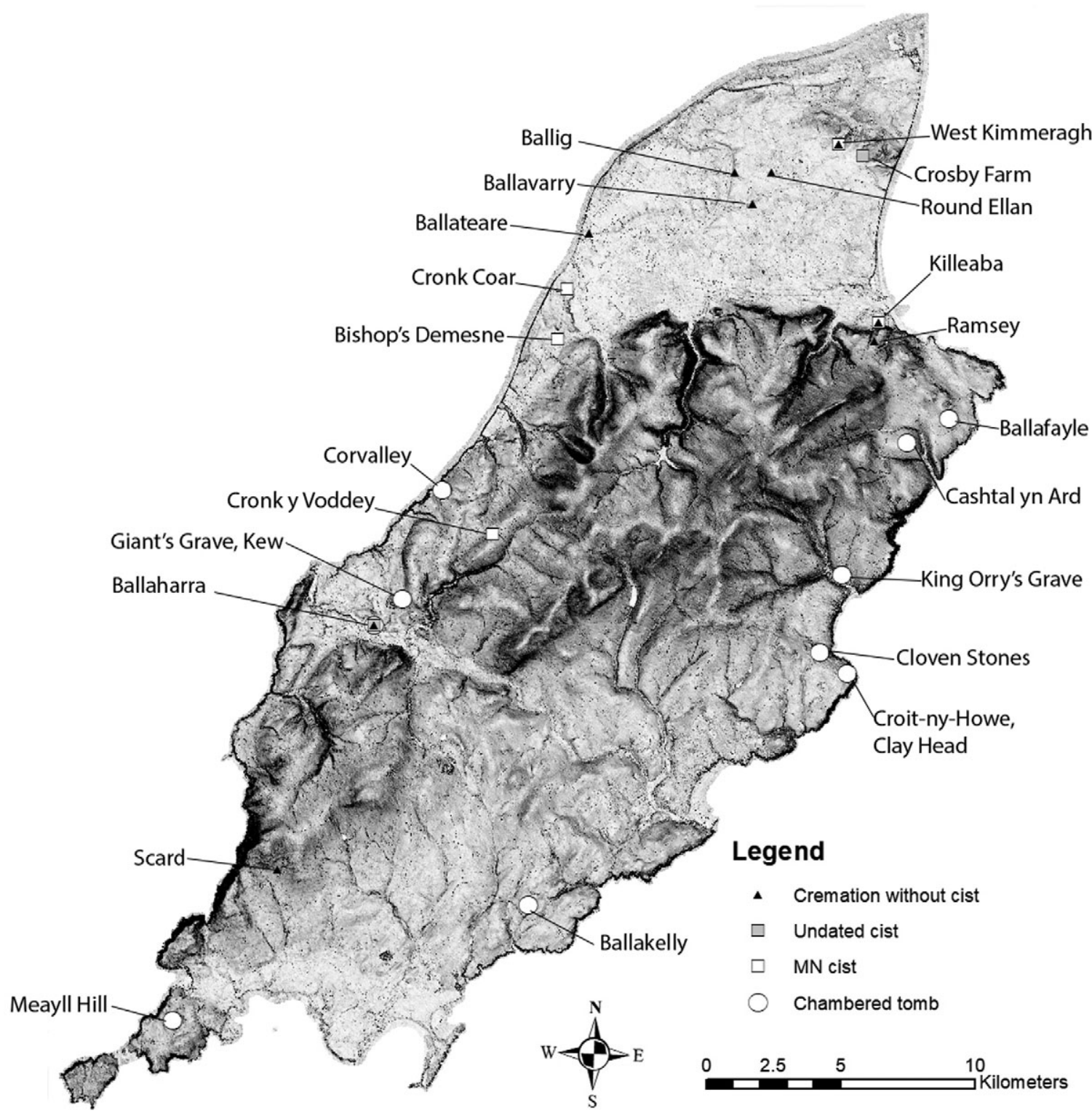

Fig. 4.

Map of the Isle of Man showing the location of chambered tombs, Middle Neolithic cists, Middle to Late Neolithic cremation deposits, and undated cists (image(s) derived from Isle of Man Survey geographic datasets and reproduced with permission under Licence No. ACA/1043 @ Crown Copyright, 2020, Department of Infrastructure, Isle of Man)

radiocarbon dates from cist burials here and elsewhere in Britain and Ireland. Many other cists excavated on the Isle of Man in the 19th or 20th centuries cannot now be dated as they either lacked human remains or these were not retained following excavation. Some of these were atypical for Early Bronze Age cists, such as that at Crosby Farm (MNH NMHER 381), excavated by A.M. Cubbon in 1959, which was constructed from packed 'glacial boulders' 'in the absence of a cist proper ...' with just a hollow in the earth with cremated remains (now lost) under the $6 \mathrm{ft} 6$ in $(1.98 \mathrm{~m})$ cover slab (Cubbon n.d.). One more set of human remains from a cist just outside the chambered tomb at Ballahara remain undated (these have 


\section{Fowler et al. CHANGE \& DIVERSITY, NEOLITHIC MORTUARY PRACTICES, ISLE OF MAN}

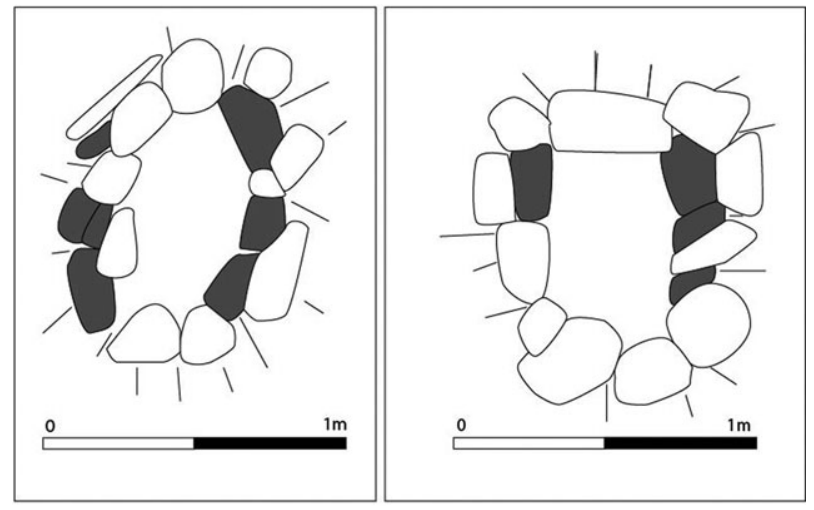

Fig. 5 .

The 'boulder cist' at West Kimmeragh. Left: upper course; right: lower course (source: Garrad 1987, redrawn by R.J. Crellin)

recently been found in the Duckworth Collection). The cist contained the unburnt remains of at least three individuals - an adult male, a young adult male, and a 10-12 year old child - and two tiny shale or jet beads (Higgins \& Davey 2017, 153; the osteological analysis is from 1975 by Denston and Allen (2017)). As the human remains were not reported as cremated they may not derive from the same Middle Neolithic tradition we outline here but a new osteological assessment and dating programme for these, and further remains from the tomb at Ballaharra (also in the Duckworth), should now be a priority.

A third distinctive practice seems to have also developed just after the middle of the 4th millennium: the deposition of cremated remains in cemeteries along with earthfast Ronaldsway Jars.

RETHINKING RONALDSWAY: BURIALS OF CREMATED REMAINS IN THE MIDDLE AND LATE NEOLITHIC OF THE ISLE OF MAN

Ronaldsway pottery is found either as broken fragments in scatters, hollows, and pits, or as complete jars buried in the earth. Earthfast vessels are sometimes found covered with a slate lid and are found singly, in pairs, or in groups, and are known from the large cemeteries at Ballateare and Killeaba (Table 2). The cemetery at Ballateare, Jurby, was discovered by Gerhard Bersu during the excavation of a Viking burial mound in 1946 . The site appears to have accumulated around a dozen Neolithic burials and one Early Bronze Age burial and saw the construction of one or more undated wooden structures and an undated ring-ditch some time before the Viking mound was constructed. Previous dates from Ballateare are Late Neolithic or Early Bronze Age, but the new dates also indicate Middle Neolithic burial activity (Table 1; Fig. 8). The clustering of similar dates suggests sporadic episodes of deposition, some potentially quite brief, and each with a different spatial focus at the site. The earliest of the Middle Neolithic cremation deposits are clustered to the east of the site, followed by Middle and Late Neolithic cremated remains, mostly associated with Ronaldsway Jars, in the south/centre of the site. Cremation XVII, which has an Early Bronze Age date, lay within what may have been a ring-ditch, to the north. Far from being an exclusively Late Neolithic cemetery, the site was used and re-used periodically over many generations. Three, possibly four, of the individuals dating to the Late Neolithic were adolescents (Gamble 2017f; Appendix S.1).

The suite of dates reported here include an Early Neolithic and an Early-Middle Neolithic date from cremated remains in discrete deposits at Ballateare: 3638-3525 cal BC (OxA-36424; Table 1) from Cremation XIV and 3629-3374 cal BC (OxA-36422; Table 1) from Cremation IV. These suggest the cemetery was in use from some time before $3500 \mathrm{cal} \mathrm{BC}$ and so possibly overlapped with the use of chambered tombs. Later dates from Cremations IX and XV indicate further deposition at Ballateare in the period 3350-3100 cal BC. In between these dates, the earliest date so far associated directly with a Ronaldsway vessel on the island, 3516-3367 cal BC (OxA-36421), derives from Cremation I. This small deposit of cremated bone was found within a Ronaldsway Jar along with a miniature pot, half of a snapped flint blade, and the end of a tiny bone pin with a bulbed end (Fig. 9). The latter is similar to barbell bone pins found in some Linkardstown burials and mushroomheaded antler pins found in passage tombs in Ireland (Herity 1982, 249, 283-4). While it is possible that earlier cremated remains were reburied with this vessel because they had been disturbed during digging at the Middle Neolithic cemetery, it is also possible that Ronaldsway vessels originated earlier than previously thought and were incorporated into a broader practice of burying cremated remains. ${ }^{7}$ The vessel containing Cremation I at Ballateare does not seem out of keeping with developments in Middle Neolithic ceramics in Britain and Ireland, where bowls were becoming 

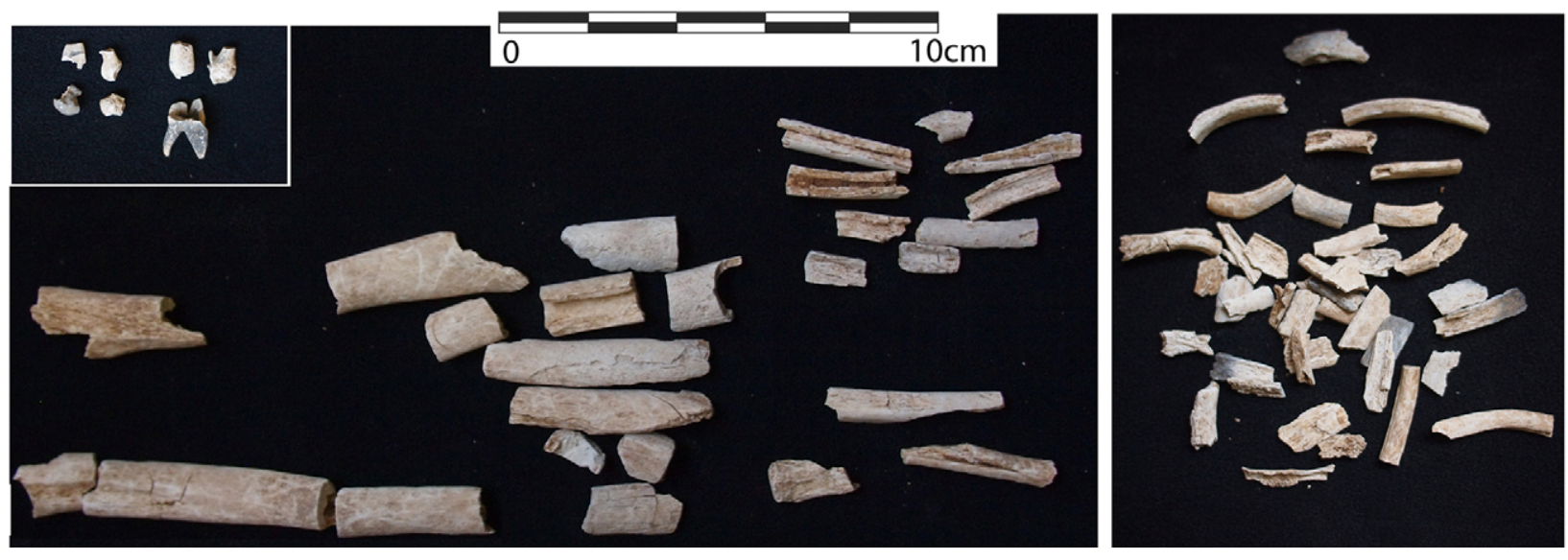

Fig. 6.

Cremated human remains from the 'boulder' cist at West Kimmeragh photograph: M. Gamble, with kind permission of the Trustees of Manx National Heritage)

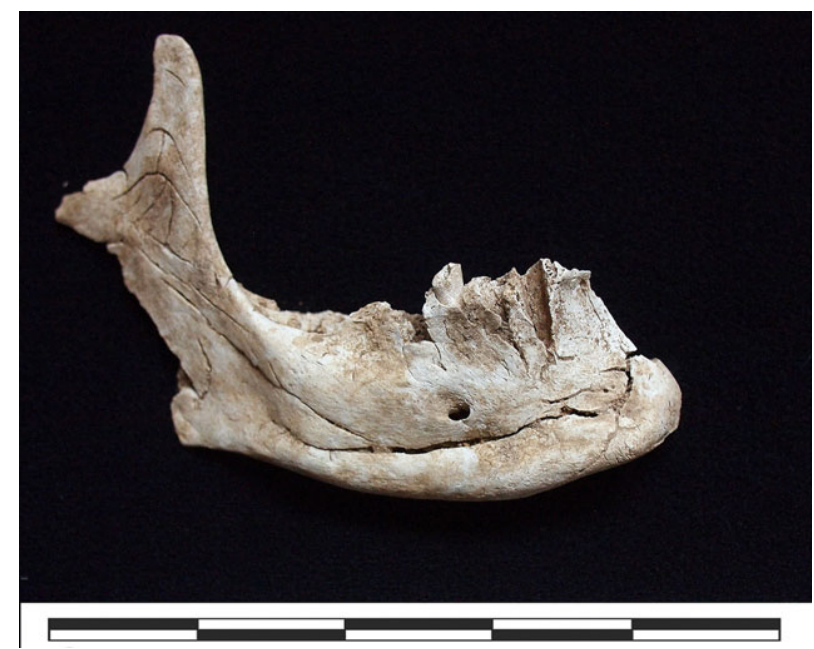

Fig. 7.

Cremated mandible from the cist at Bishop's Demesne (photograph: M. Gamble, with kind permission of the Trustees of Manx National Heritage)

thicker-walled and less carinated than before (cf. Sheridan 1995). While Ronaldsway pottery was less frequently and less intensively decorated than Middle Neolithic impressed wares in Britain and Irish Neolithic bowls, some were marked with circular depressions around the rim (as was a vessel from Ehenside Tarn, Cumbria: Herity 1982, 398). We suggest that Ronaldsway vessels could potentially date from as early as $c .3400 \mathrm{cal} \mathrm{BC}$, making their genesis roughly contemporary with Peterborough Ware pottery in Britain (Ard \& Darvill 2015). The vessels were sometimes deployed in a tradition of burying cremated bone in pits which might have started some time before the development of this ceramic tradition. Burials in cists also took place within some of the same timespan that cremated remains were deposited in pits.

The other large burial ground which has been relatively well-published is at Killeaba, Ramsey, fairly near the densest concentration of tombs on the island (Cubbon 1978; Crellin 2015; 2017). This glacial mound housed at least 20 different features containing human remains, including timber-lined pits, cists, and pits containing cremated remains. Five new dates on deposits of cremated remains here fall between 3600 and 3100 cal BC. A timber-lined pit (T1: Fig. 10) was dated in the 1970s using charcoal to 33292893 cal BC (BM-839; Table 1) (Cubbon 1978, 87). The cremated bone from this pit dated by the Round Mounds Project gave a result of 3520-3371 cal вC (OxA-36492; cremation VII; Table 1). The date of 3482-3102 cal BC (OxA-36491; Table 1) for Cremation II was surprising, since Cubbon describes this deposit as stratigraphically above a pit containing an Early Bronze Age cist - though there are no section drawings to demonstrate that and its exact position in the published section is unclear (Cubbon 1978, 75, fig 4). Cremation II is clearly stratigraphically above the timber lined pit T1 and Cremation VII, however. Cremation I in Cist VI, which is stratigraphically above Cremation II, provides a date of 3494-3105 
C. Fowler et al. CHANGE \& DIVERSITY, NEOLITHIC MORTUARY PRACTICES, ISLE OF MAN

TABLE 2. SITES WHERE EARTHFAST JARS WERE BURIED COMPLETE IN THE GROUND

\begin{tabular}{|c|c|c|c|c|}
\hline Site & MNH NMHER & Type of site & No. Earthfast Jars & $\begin{array}{l}\text { Presence of cremated } \\
\text { remains in vessels? }\end{array}$ \\
\hline Ballacross & 0014 & Earthfast Jar site & 1 & No \\
\hline Ballacubbon & 1867 & Earthfast Jar site & 1 & No \\
\hline Ballagawne & 1943 & Earthfast Jar site & 2 & No \\
\hline Ballahott & 0002 & Earthfast Jar site & 1 & No \\
\hline Ballakeigh & 0398 & Earthfast Jar site & 1 (poss. 2) & Yes \\
\hline Ballaquayle & 0253 & Earthfast Jar site & 2 & No \\
\hline Ballateare & 1355 & Cemetery & 7 & Yes, in 1 jar \\
\hline Ballig Bridge & NA & Earthfast Jar site & 3 & Yes, in 2 jars \\
\hline Billown & NA & Occupation area & 7 & No \\
\hline Cleigh Rooar & 0128 & Earthfast Jar site & 1 & No \\
\hline Colby & 0015 & Earthfast Jar site & 1 & No \\
\hline Colby Mooar & 1869 & Earthfast Jar site & 1 & No \\
\hline Crossag & NA & Earthfast Jar site & 1 & No \\
\hline Earybedn & 1623 & Earthfast Jar site & 1 & No \\
\hline Gob Y Volley & 0459 & Earthfast Jar site & 1 & No \\
\hline Killeaba & 0231 & Cemetery & 2 & No \\
\hline Orrisdale Brooghs & NA & Earthfast Jar site & 1 & No \\
\hline Orridsale Head & 0826 & Earthfast Jar site & 1 & No \\
\hline Round Ellan & 1163 & Earthfast Jar site & 2 & Yes \\
\hline Ronaldsway Airport & 0107 & Earthfast Jar site & 2 & No \\
\hline Scard & 0065 & Earthfast Jar site & 9 & Yes, in $5+$ cases \\
\hline Scholaby & 0195 & Earthfast Jar site & 1 & No \\
\hline Skyhill & 0532 & Earthfast Jar site & 1 & No \\
\hline
\end{tabular}

cal BC (OxA-36490). This cist, c. $0.6 \times 0.6 \mathrm{~m}$ and containing the cremated remains of $c .50 \%$ of the skeleton of a child under 4 years old (Gamble 2017g; Appendix S.1), can be set among the Middle Neolithic cists discussed above.

A Bayesian model based on the stratification of the dates for cremations I, II and VII has a very good agreement, particularly at 2 sigma (Fig. 11; Table 3$)$. The $68.3 \%$ probability model suggests that all three sets of remains within the feature could have been from individuals who died within a year of each other or up to 395 years apart. The earliest start date for deposition would be $3544 \mathrm{cal} \mathrm{BC}$ and the latest start date $3370 \mathrm{cal} \mathrm{BC}$; the earliest end date is 3366 cal $B C$ and the latest end date is $3129 \mathrm{cal} \mathrm{BC}$. If all the activity in this sequence took place within one year, that would therefore lie within the period 3372-3367 cal BC (the earliest modelled date for Cremation I and latest modelled date for Cremation VII). Cremation III was probably deposited in an organic container and returned a date of 3356-3094 cal BC (95.4\%; OxA-27112; Table 1; Crellin 2015, 37). Killeaba can therefore be understood as a multi-period site beginning with a Middle Neolithic cremation cemetery, with burials in cists or in pits with organic containers. Continued use in the early 3 rd millennium is evident in the form of a second timber-lined pit (dated from charcoal), while an Early Bronze Age cist cemetery formed around the periphery of these mid- and Late Neolithic features. The scattered human remains of Cremation $\mathrm{X}$ were found along with a Food Vessel ('pot 5') and unexpectedly produced a date of 3516-3362 cal BC (OxA-36493; Table 1): Gamble (2017g; Appendix S.1) notes that some of this bone was 'water worn and eroded', and it seems likely that the remains were encountered during an Early Bronze Age re-use of a much older cemetery and redeposited along with a vessel of a kind that frequently accompanied the dead in this later period.

Since the dates from the cists reported in this and the previous section, and Cremation $\mathrm{X}$ with the Food Vessel, are earlier than expected, we have considered the possibility that they could be affected by an old wood effect: since carbon is exchanged between bone apatite and fuels during cremation, if very old wood were used as fuel in a cremation pyre it could affect the radiocarbon signature (Snoeck et al. 2014). Preserved ancient wood (sometimes called 'bog oak') might also have been present in the curragh wetlands in the northern part of the island (Cubbon 


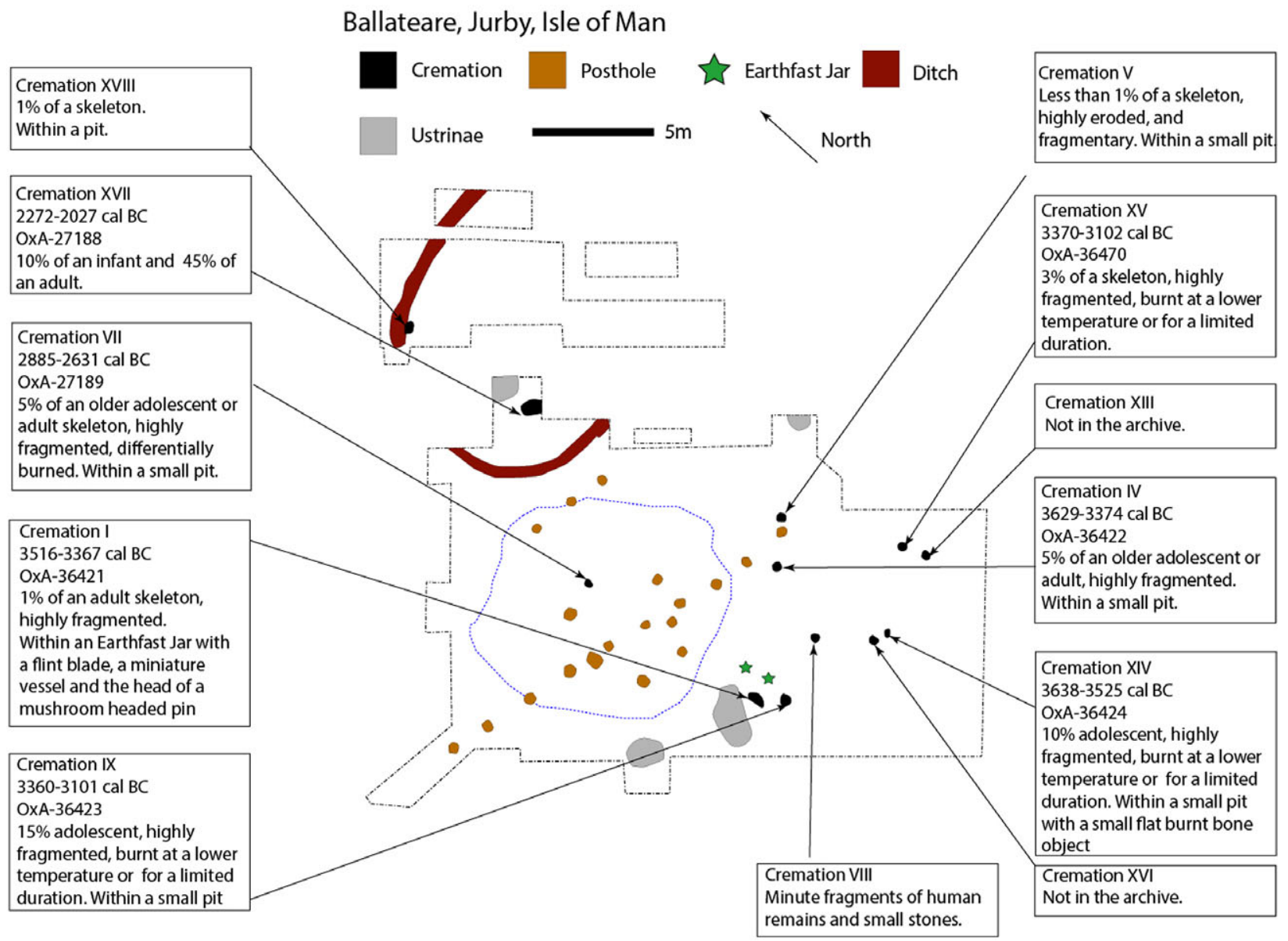

Fig. 8 .

Plan of the cremation cemetery at Ballateare (redrawn and annotated by R.J. Crellin \& C. Fowler; site plan after Bersu 1947)

1978, 87). However, such wood would be wet on extraction, hard and dense, and unlikely to burn well due to mineralisation. It therefore seems unlikely it would be used in cremation pyres. Using such wood would be unlikely to consistently offset the dates by an entire millennium or more, and other deposits associated with Early Bronze Age artefacts or in short cists dated in the same study have returned mid-late 2 nd millennium dates as expected, as have other deposits dated from Ballateare and Killeaba. Ronaldsway vessels present at both sites are also consistent with Neolithic dates.

Beyond these two cemeteries, many Ronaldsway jars were recovered as chance finds during ploughing and in most cases no archaeological work has been carried out in the surrounding area to locate other archaeological evidence. At sites such as Billown (Darvill 1996; 1997) and Ballig (Burrow 1997, 38), excavation in the surrounding area has revealed further features. Two of the earthfast jars at Billown were found in association with post markers (Darvill 1996; 1997). None of the sites where earthfast jars have been found in isolation has been radiocarbon dated and they have simply been presumed to date to the Late Neolithic. Small quantities of cremated remains have been found within earthfast vessels, although many more have been found empty (Table 2). At Scard, a line of four evenly spaced jars were found during construction work and burnt bone and charcoal were recovered but it is unclear if these were found within the vessels or not (Kermode 1902). Later archaeological excavation at the same site 


\section{Fowler et al. CHANGE \& DIVERSITY, NEOLITHIC MORTUARY PRACTICES, ISLE OF MAN}

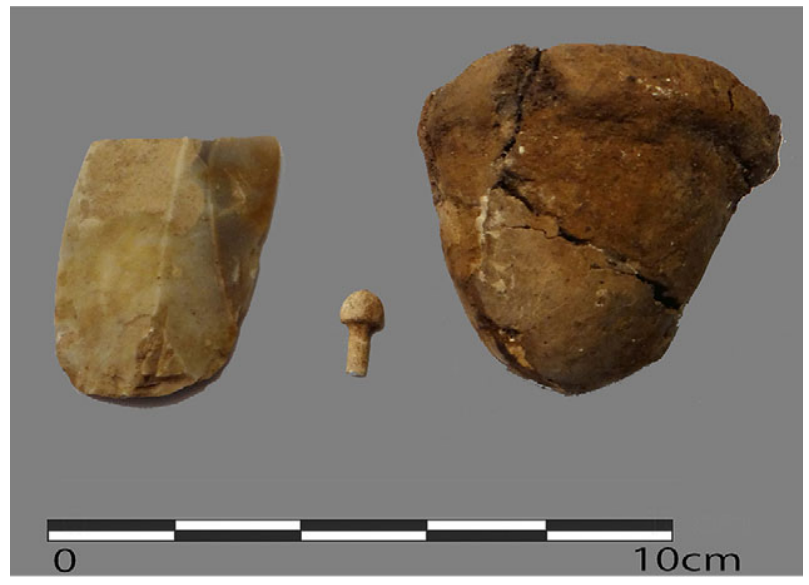

Fig. 9.

Artefacts found with Cremation I at Ballateare. Left: broken flint blade; middle: fragment of a barbell pin; right: miniature vessel. (top images from the Manx Museum, bottom photograph by R.J. Crellin; both used with kind permission of the Trustees of Manx National Heritage)

revealed a further five jars, each of which was found to contain charcoal and a few fragments of cremated remains (Burrow 1997, 44). At Round Ellan two jars were discovered and damaged during ploughing so only their bases remained. These bases contained cremated remains (Burrow 1997, 44).

Three new dates, all within the period c. 3100-2900 cal BC, are from contexts associated with fragmented Ronaldsway vessels at Ramsey, West Kimmeragh, and Ballavarry. The character of at least the latter two sites is very different from the cemeteries at Killeaba and Ballateare and potentially different from 'earthfast jar' sites. They contain fragmentary debris from occupational activity which may, perhaps, derive from midden material; human remains seem to be included within this mixed debris rather than singled out for special treatment. The cremated remains of $c .1 \%$ of an individual at West Kimmeragh were found in small hollows left by the removal of stones from a cobbled surface (Garrad 1987, 422; Gamble 2017c; Appendix S.1). Ballavarry is a little better understood, although the excavation record lacks section drawings and the nature of the site is ambiguous. Three intersecting pits contained a combination of sherds from at least 21 Ronaldsway vessels, one sherd identified by Burrow (1997) as a shouldered bowl, flint cores, saws, blades and scrapers (including hump-backed scrapers), two knives and an awl, and an incised slate plaque $c .55$ mm long (Garrad, 1984b, 165; Jones et al. 2016): some of the linear, diamond, cross-hatched and zigzag motifs sit within a range of motifs found on Grooved Ware pottery and passage tomb decoration. As well as the date we obtained from the cremated remains, a date from charcoal and three from carbonised residue on sherds exist for Ballavarry, spanning $c$. 3100-3000 to c. 2400-2200 cal BC. Garrad gives no details about the fill or fills of the pit. The material may have been deposited from a very old midden or built up in an open feature (such as a tree throw) gradually over a very long period of time.

The inclusion of the decorated plaque at Ballavarry, the Grooved Ware pottery at Glencrutchery, and the Grooved Ware and incised plaques at Ronaldsway suggest participation in wider social networks some time after c. $3000 \mathrm{cal}$ BC. Since some Ronaldsway vessels and cremation cemeteries pre-date this by centuries, it appears that Grooved Ware vessels and symbols were partially and sporadically incorporated into existing local practices. This resonates with the incorporation of Grooved Ware into existing activities at passage tombs in the Boyne Valley, Ireland, in the same period (Carlin 2017). Yet Grooved Ware pottery was not seen as an alternative to or replacement for Ronaldsway Jars in that no earthfast Grooved Ware pots have yet been found. Indeed, the dates on carbonised residues on Ronaldsway pottery from Glencrutchery suggests that this style of ceramic was still in use until at least the middle of the 3rd millennium (Burrow \& Darvill 1997), and possibly through to $c .2300 / 2200$ cal BC. However, there are no dates from cremated human remains associated with Ronaldsway Jars later than that from Ballavarry (3076-2898 cal BC; OxA-36487; Table 1), the remainder all being from carbonised residues on vessel sherds. Fragmented debris and pit deposits appear to be a consistent feature of Late Neolithic occupation sites, in contrast with the so-far unique structure of the Ronaldsway house. Like the Middle Neolithic cists, sites containing Ronaldsway vessels are well represented in the northern lowland of the island where no chambered tombs have yet been found.

On this basis we suggest that the use of Ronaldsway pottery continued across the Middle and Late Neolithic, ${ }^{8}$ and that it was used in different ways over time. We suggest that early Ronaldsway Jars were sometimes buried alongside cremated bone, the deposition of which started c. $3500 / 3400 \mathrm{cal} \mathrm{BC}$, as intact 


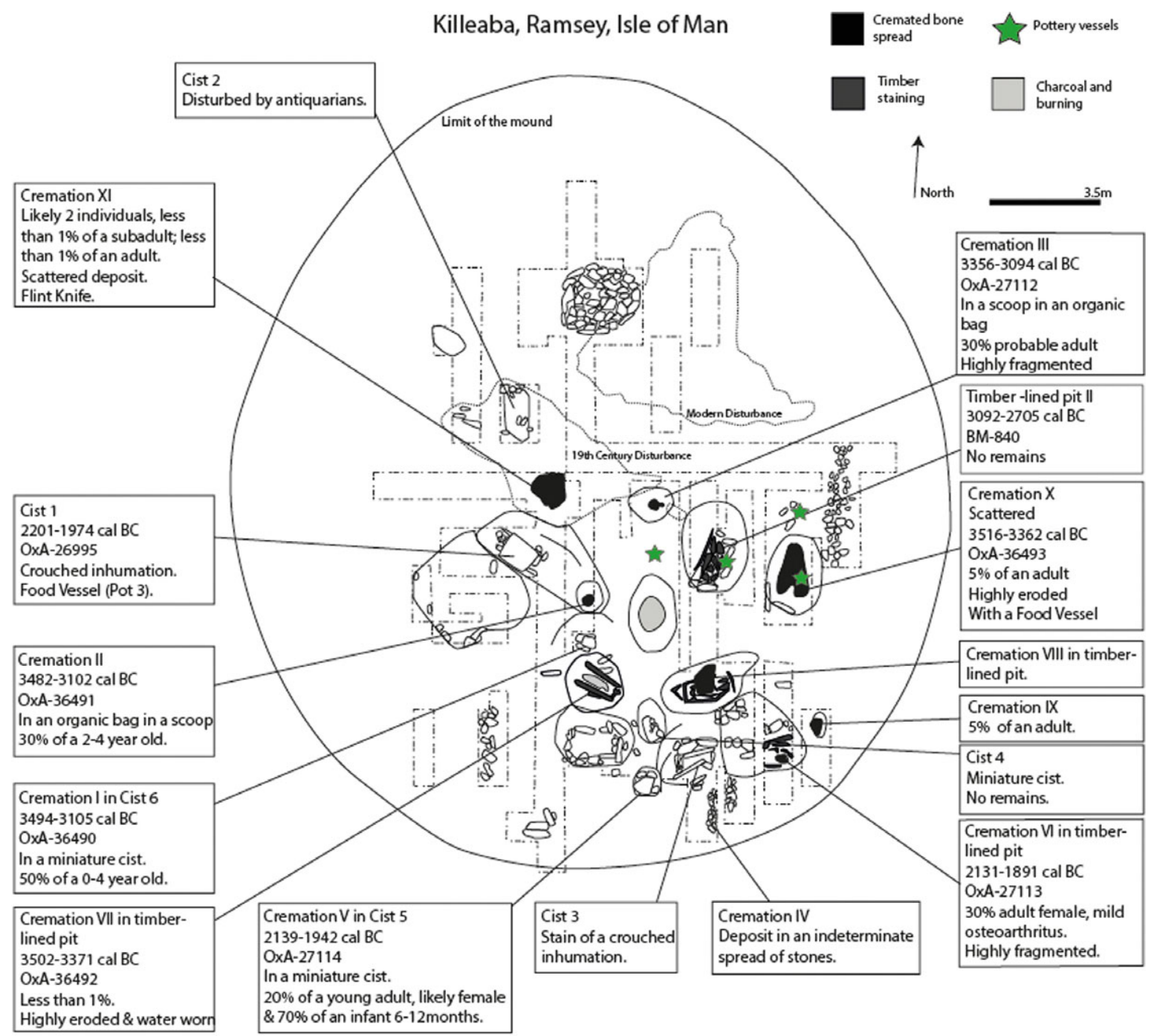

Fig. 10.

Plan of the cemetery at Killeaba (redrawn and annotated by R.J. Crellin \& C. Fowler; site plan after Cubbon 1978)

vessels in pits. Ronaldsway Jars might have provided an alternative container to a cist while other cremated remains deposited within pits may have been within organic containers. Yet examples of these vessels which do not contain any human remains are found at cremation cemeteries, and elsewhere in groups, pairs or singly. Either human remains and artefacts were removed from these vessels during the period (perhaps during a multi-stage mortuary sequence) or the jars were more commonly used to contain something else - water or organic material, perhaps.
They have been interpreted as shafts or small chambers to temporarily contain funerary deposits (Fowler 2004, 94; Crellin 2015, 33-4), for making offerings (Bersu 1947, 169), or interacting with the underworld or the dead (Darvill 2000, 379; 2012, 38). These large, round-based vessels were designed to be supported by the surrounding earth, and the coarse fabric of Ronaldsway pottery mimics earth (Crellin 2017). These jars materialised the walls of a pit in an enduring way, allowing repeated access to that pit. The use of these jars can therefore be situated 


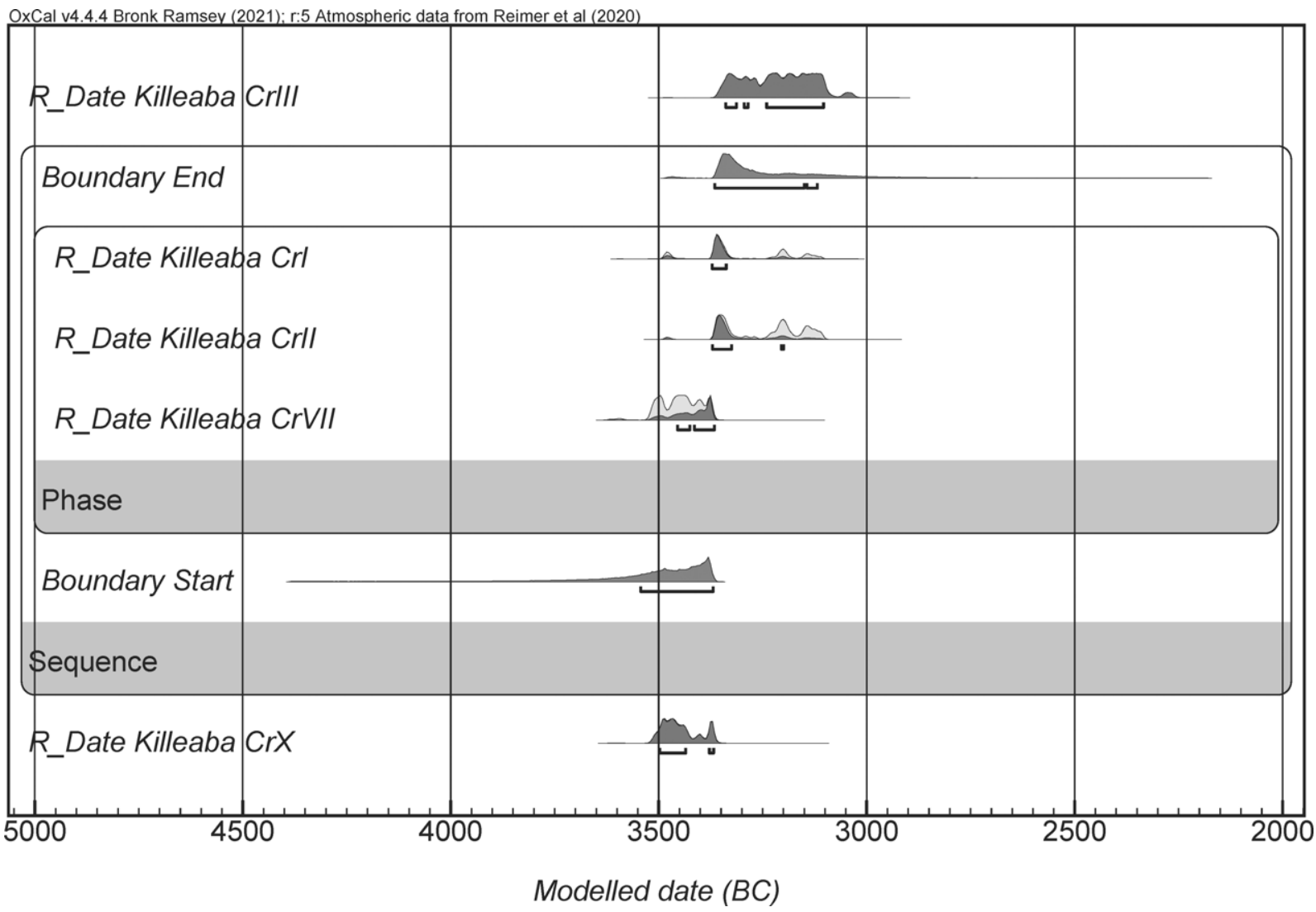

Fig. 11.

Plot of the Bayesian modelling of the radiocarbon dates from Killeaba cremations I, II \& VII at $68.3 \%$ probability $(1 \sigma)$. Dates are calibrated using OxCal 4.4.2 (Bronk Ramsey 2009; r:5 atmospheric data from Reimer et al. 2020)

within broader Neolithic practices of pit-digging and pit deposition (cf. Anderson-Whymark \& Thomas 2012). But, increasingly, some jar fragments were deposited in contexts that also contained small amounts of burnt human remains.

Finally, not all Late Neolithic mortuary deposits included only small amounts of human bone. A date of 3009-2623 cal BC (BM-769; Table 1) from cremated bone in a $1 \mathrm{~m}$ diameter pit $c .1 \mathrm{~m}$ outside the kerb of a chambered tomb at Ballaharra (Higgins \& Davey 2017, 152) derives from an unusual, massive deposit of over $25 \mathrm{~kg}$ of cremated bone from 34 or more individuals, including a combination of male and female adults, and subadults (based on a report from 1975: Denston \& Allen 2017). It is the closest indication of anything like re-use of a chambered tomb in this period but was kept a short distance from the tomb and did not disturb its integrity.

\section{THE CHANGING EFFECTS OF MORTUARY DEPOSITION}

It is now possible to propose a sequence of mortuary practices during the Neolithic on the Isle of Man along with a revised chronology for Ronaldsway pottery. Of course, we are only able to comment on mortuary practices which resulted in the deposition of remains and it is likely that other treatments of the dead left no trace in the archaeological record. Nonetheless, the deposition of cremated remains persisted throughout the Neolithic and the contexts in which these were deposited were more diverse during the Middle Neolithic than earlier or later.

Ballafayle provides clear evidence that the Isle of Man was involved in the Mesolithic-Neolithic transition seen in neighbouring regions by at least $3800 \mathrm{cal}$ $\mathrm{BC}$, and likely earlier; this accords with the chronology suggested by Whittle et al. (2011, 560-1; 852). The bodies of at least two individuals were interred intact 
THE PREHISTORIC SOCIETY

Table 3. RESULT OF THE BAYESIAN MODELLING OF THE RADIOCARBON DATES FROM KILLEABA CREMATIONS I, II, \& VII AT $68.3 \%$ PROBABILITY $(1 \sigma)$

\begin{tabular}{|c|c|c|c|c|c|c|c|c|}
\hline \multirow[t]{2}{*}{ Name } & \multicolumn{3}{|c|}{ Unmodelled (cal BC) } & \multicolumn{3}{|c|}{ Modelled (cal BC) } & \multicolumn{2}{|c|}{$\begin{array}{c}\text { Indices } \\
A_{\text {model }}=120.6 \\
A_{\text {overall }}=119.1\end{array}$} \\
\hline & From & To & $\%$ & From & To & $\%$ & Agreement & Convergence \\
\hline R_Date Killeaba CrIII & 3339 & 3104 & 68.3 & 3339 & 3104 & 68.3 & 99.8 & 99.6 \\
\hline Span & & & & 0 & 395 & 68.3 & & 96.8 \\
\hline Boundary End & & & & 3366 & 3119 & 68.3 & & 98.3 \\
\hline R_Date Killeaba CrI & 3485 & 3191 & 68.3 & 3372 & 3338 & 68.3 & 130 & 99.8 \\
\hline R_Date Killeaba CrII & 3366 & 3121 & 68.3 & 3371 & 3200 & 68.3 & 119.8 & 99.4 \\
\hline R_Date Killeaba CrVII & 3513 & 3374 & 68.3 & 3455 & 3367 & 68.3 & 95.9 & 99.6 \\
\hline Boundary Start & & & & $\begin{array}{l}\text { Phase } \\
3544 \\
\text { equence }\end{array}$ & 3370 & 68.3 & & 97.8 \\
\hline R_Date Killeaba CrX & 3497 & 3369 & 68.3 & 3498 & 3369 & 68.3 & 99.1 & 99.6 \\
\hline
\end{tabular}

Dates are calibrated using OxCal 4.4.2 (Bronk Ramsey 2009; r:5. Atmospheric data from Reimer et al. 2020)

in a wooden chamber before the chamber was set on fire. The collapsed chamber and the human remains do not seem to have been subsequently disturbed; after this dramatic, memorable event, the mound marked the presence of the dead but their remains were sealed in and consigned to the past. They were not collected or disturbed. At chambered tombs the remains of the dead were stored in impressive enduring structures with forecourts and entrance chambers which facilitated and directed interaction with the dead (Fowler $2001 ; 2004 ; 2008)$. There is too little information on human remains from the chambered tombs to know whether bodies were interred intact or after processes such as exposure or excarnation, though we know that in some cases the dead were cremated prior to inclusion. No artefacts were found with the remains at Ballafayle, while several chambered tombs have yielded fragmented ceramics. It is not clear whether these were introduced with the human remains or later.

The deposition of cremated remains in pits, cists, and cemeteries suggests previously unrecognised diversity in mortuary practices on the island c. 3500-3100 cal BC. Three of the cists lie on the relatively flat north-eastern plain where there are no megalithic tombs, while Cronk y Voddee lies in the lee of a hill on the north of the island, c. $2.5 \mathrm{~km}$ inland of Corvalley and c. $4 \mathrm{~km}$ north-east of the chambered tomb at Ballaharra. Cists were used to deposit the cremated remains of at least two children and a small woman or adolescent in what may have been isolated locales or, at Killeaba, a nascent burial ground. The use of a small cist chamber to bury the remains of a single individual was very different to the repeated use of large, multiple chambers known at chambered tombs. Other than the one bone bead from Kimmeragh, the absence of grave goods in the cists is notable. If items personal to the deceased were retained, perhaps the living maintained ties with the dead that way. If so, there may be a contrast between the use of chambered tombs where the living and the dead (and the dead and the dead) were connected or integrated during visits, and cists where the bodily remains of the dead were separated from the living even if their personal items were retained (cf. Fowler 2001). While cists could potentially be opened repeatedly, as has been suggested for some Early Bronze Age cists (eg, Appleby 2013, 92; Fowler 2013, 231, 245; Jones 2017; Brück 2019, 24-5, 38-9), there is as yet no indication that this took place, and the weight and the proportion of the skeleton surviving in cists was much higher than in jars or pit burials. During the same period, cremated remains were deposited in organic containers or ceramic jars in small cemeteries, including adults, adolescents (particularly at Ballateare), and young children (at Killeaba). While four of the five Middle Neolithic cists included over half of a cremated skeleton, remains placed within Ronaldsway Jars are very partial (usually less than $5 \%$ of a skeleton). Cremation I in a Ronaldsway Jar at Ballateare included a bone pin fragment with affinities with Irish bone pins, a broken flint blade, and a miniature vessel - these may be interpreted as grave goods in an early use of a Ronaldsway Jar; a practice 


\section{Fowler et al. CHANGE \& DIVERSITY, NEOLITHIC MORTUARY PRACTICES, ISLE OF MAN}

which did not come to form a tradition. The Middle Neolithic is therefore best characterised as a period of diverse mortuary contexts which could be grouped, in pairs, or isolated.

In the centuries around 3000-2900 cal BC, cremated remains and broken jar pottery appear together in pits which seem to relate to occupation activity. Those human remains deposited in pits with vessel fragments were no more than scraps of bone. While cremation will have destroyed some of the remains, and incomplete recovery from the pyre is a possibility, it is also possible that the remains were divided up and given to different people or dispersed at different places. If so, this seems to have increasingly dispersed cremated remains during the period - with the exception of the extraordinary deposit of over 34 individuals in $25 \mathrm{~kg}$ of bone outside a now-ancient chambered tomb at Ballaharra. It is possible that the deposits of human remains in jars were 'token' or 'symbolic' in nature (cf. Willis 2019, 414) but the jars, buried up to their mouths and often covered with a slate slab, left the remains accessible, so perhaps human remains were removed from such vessels after some time as deliberately as they were placed within them. If Early Neolithic chambered tombs can be seen as shrines and/or repositories for the collective dead, if cists and jars were repositories for a portion of the remains of just one or two individuals, and if burials in pits at cemeteries or with intact jars allowed access to separate deposits of fragmented remains, then later pits containing occupation debris, such as Ballavarry, immersed the heavily fragmented remains of the dead into the landscape and left these tiny traces of the dead at sites with a more occupational than 'mortuary' character. The artefacts within the pit at Ballavarry are not grave goods but their inclusion situated the remains of the dead alongside the remains of daily life.

Ballafayle and the chambered tombs were visible structures which left an enduring trace on the landscape; the cists were small subterranean chambers which disturbed only a small area of vegetation and some were positioned on locally visible prominences. The cremation cemeteries were somewhere in between: they were used successively to bury the dead; and if they were visited and offerings made at or in Ronaldsway Jars, for instance, they may have been repeatedly tended. Sites like Round Ellan and Scard suggest that jars were used to contain the dead at other cemeteries. By contrast, the inclusion of small quantities of human remains in pits suggests that the dead were not commemorated through monuments but hints that their remains may have been retained at occupation sites. Each of these practices had a different temporal effect: tombs visibly manifested the enduring community of the dead (Fowler 2004; 2008); cists may have kept the dead secluded and become quickly overgrown; cemeteries saw new burials periodically and may have been cleared and renewed each time. By the end of the Neolithic at least some of the dead were seemingly dispersed in the landscape of the living rather than given dedicated burial grounds. Indeed, such dispersal or immersion may have been a widespread practice all along, leaving no archaeological trace.

\section{MIDDLE AND LATE NEOLITHIC MORTUARY PRACTICES ON THE ISLE OF MAN IN WIDER CONTEXT}

There are interesting comparisons between this Middle-Late Neolithic sequence on the Isle of Man and those of neighbouring regions. Currently, more than 45 graves in Britain and Ireland have been identified as containing unburnt remains radiocarbon dated to the Middle Neolithic, and many more asyet undated burials that may date to this period (E. Harrison, pers. comm.). Furthermore, the number of deposits of cremated remains dated to this period has been growing steadily over the last 30 years (Willis 2019).

Ovoid cists of a similar size to the Middle Neolithic cists on the Isle of Man were used for burials in Britain and Ireland at this time, but rather differently. In Ireland, 'Linkardstown-style' burials were placed in caves, rock fissures, or cists during the period c. 3650-3300 BC (Brindley et al. 1983; Brindley \& Lanting 1989-90; O'Sullivan \& Downey 2019). Remains include men, women, and children, sometimes singly but sometimes with several sets of remains in the same feature. Linkardstown burial practices were relatively diverse, including examples of crouched or flexed inhumations (eg, Dublin North City: Ryan 1981, 142), extended inhumation (Drimnagh: Kilbride-Jones et al. 1939), disarticulated remains (eg, Ballintruer More, Wicklow; Raftery 1973; Brindley et al. 1983), and, in one case, cremated remains accompanying an inhumation (Jerpoint West: Ryan 1973). Small cists were also inserted or incorporated into some passage tombs in Ireland, as at the Mound of the Hostages where three cists contained burnt and unburnt remains from multiple individuals 
including children (O'Sullivan 2005). Middle Neolithic cists have also been found in the Peak District, here containing unburnt remains. At Liff's Low the flexed burial of an adult male was accompanied by an unusual decorated flask, an antler macehead, boar's tusks, arrowhead, flint axeheads, and flint knives (Loveday \& Barclay 2010). The skeleton has been dated to 3360-3090 cal BC (Jay et al. 2019 , 493-4). At Bee Low a cist containing an articulated adult male dating to $3340-3010 \mathrm{cal}$ BC was used for six or seven successive inhumations, but the timeframe for this is unclear (a Beaker was also found within the cist) (Jay et al. 2019, 494-5). Cist burials from this period are otherwise rare.

Linkardstown cists and Peak District cists were incorporated into mounds, which seems to have been the case at Bishop's Demense but not West Kimmeragh Boulder Cist or Cronk y Voddee, although mounds could easily have been destroyed prior to the sites being recognised. Linkardstown cist architecture is also more elaborate, sometimes with two or three layers of cist walls and cover stones. While we are dealing with a small number of sites, the cists on the Isle of Man do not seem to be skewed towards any particular age group and the only thing that can be said about sex is that one of those buried was possibly female. The remains in cist burials on the Isle of Man were cremated while those in central Britain were seemingly not, ${ }^{9}$ and nor were most Linkardstown burials. The latter were frequently accompanied by artefacts, including finely-decorated round-based bowls, bone pins, bone toggles, and in one case a stone axehead (Herity 1982, 255-8). While Herity (ibid., 265) identified vessels from Linkardstown, Glencrutchery, and Ronaldsway as all yielding similar 'broad-rimmed' vessels, the cist burials from the Isle of Man have none of the suite of artefacts seen with Linkardstown burials. They also do not share the presence of grave goods with Liff's Low, nor, reaching further afield to Duggleby Howe in Yorkshire, with the two/three burials in the shaft grave which have been Bayesian modelled to c. 3530-3480 cal BC for burial $\mathrm{K}$ (an adult in a wooden coffin with a decorated bowl) and 35103480 cal BC for I (adult male with cranial trauma) and the accompanying cranium $\mathrm{J}$ (adult with cranial trauma and blade cut) (Gibson \& Bayliss 2009).

The diversity of Middle Neolithic burial practices also extends to shared graves or small burial grounds in Britain, though these tend to be later than
Linkardstown burials. A grave capped with small stones at Ballevullin, Tiree, dating to 3340-3090 cal BC was one of at least four graves locally and contained inhumations of a child and a 25-30 year old (probably female) who suffered from rickets (Armit et al. 2015). In north Wales, a large grave pit at Four Crosses 5 dated to 3341-2921 cal BC contained a flexed burial of an adult with an Ebbsfleet-style impressed ware bowl, a mammal mandible, and a 'pear-shaped stone', intercut by two other inhumations, possibly adolescents or adults although the bones were too decayed for analysis (Tellier 2018, 20-1, 158). As noted above, cremated remains were sometimes inserted into dolmens and chambered tombs during the Middle Neolithic in Ireland; this also occurred in parts of Britain (Kytmannow 2008; Tellier 2018, 21), and it is possible this also happened at megalithic monuments at the Isle of Man though there is as yet no direct evidence for it.

A broadly similar process of turning away from chambered tombs while burying the dead in pit graves in the mid-4th millennium can perhaps be inferred widely around the Irish Sea, although this has to be set alongside indications of Middle Neolithic deposition at existing chambered tombs and the fact that Early Neolithic burials in graves away from tombs are also more numerous than frequently discussed (E. Harrison, pers. comm.). In other regions, ceramics were included with the Middle Neolithic dead more frequently than on the Isle of Man, where there is a notable absence of Middle Neolithic impressed wares and bowls. We suggest that, sometimes, Ronaldsway pottery was an equivalent for such vessels but was only deployed in burying cremated remains in cases which did not involve cists and, even then, only in some cases.

Cremated remains are predominant in passage tombs in Ireland, and mid-late 4th millennium cemeteries of cremated remains have been located in mainland Britain: indeed, Killeaba and Ballateare can be considered as similar to a growing number of well-dated late Middle Neolithic and Late Neolithic cemeteries in Britain, including Imperial College Sports Ground, Middlesex (Powell et al. 2015), Stonehenge (Willis et al. 2016), and Forteviot, Perthshire (Noble \& Brophy 2017), all of which also included the remains of subadults. At 3100-2800 cal BC, these sites in Britain generally exhibit slightly later dates than the two cemeteries on the Isle of Man, although Landegai henge A in 


\section{Fowler et al. CHANGE \& DIVERSITY, NEOLITHIC MORTUARY PRACTICES, ISLE OF MAN}

North Wales, not far from the Isle of Man, also includes a cremated deposit dated to 3359-3013 cal BC (Tellier 2018, 20; Willis 2019, 240), and two deposits of cremated bone were placed in pits cut into a backfilled ring-ditch at Newton Poppleford, Devon; one dated to 3341-3030 cal BC included a sherd of Peterborough Ware (Rainbird \& Lichtenstein 2018). A date of 3361-3103 cal BC on cremated bone from the ditch of the Whitton Hill henge, Northumberland suggests burials of cremated remains well before the henge was built there (Fowler 2013, 111, 178), and an Early Bronze Age cist cemetery at Holly Road, Leven, Fife, also seems to have disturbed Middle Neolithic cremated remains (Lewis \& Terry 2004). Willis $(2019,412)$ has suggested that cremation cemeteries in Britain were usually located at monuments, while burials in small numbers or single burials were situated away from monuments. Whether or not this was always the case in Britain, cemeteries of cremated remains do not seem to have been associated with existing monuments on the Isle of Man.

As a whole, the diverse mortuary traditions on the Isle of Man fit well within the range of broader mortuary traditions in Britain and Ireland during the same period and, while they also exhibit some distinctiveness, the same can be said for burials in other regions. There is evidence for interplay between regions in the design of Early Neolithic monuments, such as the presence of court tombs with horned cairns on the Isle of Man, the north of Ireland, and southwest Scotland, and the fact that both cremated remains and inhumations have been found at tombs on the Isle of Man and in Ireland. The Middle Neolithic dates for cremated remains from non-megalithic contexts on the Isle of Man seem to lie in between the earliest dates from Ireland and those from Britain - although further dating of cremated remains from Britain may yet yield earlier Middle Neolithic dates. In Ireland, cremation was practised for remains deposited in some court tombs and many passage tombs, while those buried singly or in small groups in Linkardstown burials were not usually cremated. Cremation escalated during the Middle Neolithic, but while it became a feature of collective deposition at passage tombs in Ireland, on the Isle of Man cremation was adopted for single deposition in cists or pits, and cremation cemeteries began to form at Killeaba and Ballateare. This may perhaps suggest continued contact with Ireland even though some other indications of connectivity across parts of Ireland and
Britain in the Middle-Late Neolithic have not yet been located on the Isle of Man.

Signs of that wider connectivity include: similarities between antler and polished stone maceheads in Ireland and Britain (the Garboldisham macehead also sports a spiral design reminiscent of Irish passage tomb motifs: Jones et al. 2017); the possibility that disarticulated bones buried in a pit in Wiltshire derive from an adult male who had previously lived in Ireland (based on ${ }^{87} \mathrm{Sr} /{ }^{86} \mathrm{Sr}$ and ${ }^{18} \mathrm{O}$ values) and were deposited in a way known in Ireland at that time (Roberts et al. 2020, 21, 27); the passage tombs on Anglesey (Burrow 2010) and the ditchless henge at Mayburgh (Topping 1992), which have comparators in Ireland, and; the carving of motifs seen in passage grave art on vertical rock surfaces at Copt Howe and Long Meg in Cumbria (Bradley et al. 2019). As far as we know, large passage tombs with parietal art were not present on the Isle of Man, and neither were henge monuments, but the presence of Grooved Ware and two small lozenge-decorated plaques on the island after $c .3000 \mathrm{BC}$, as well as the presence of RTB axes in a few parts of Britain, suggests at least some continuing interaction between the Isle of Man and Ireland and Britain in the Late Neolithic. The circulation of these artefacts and adoption of Grooved Ware ceramic style suggests that some communities on the Isle of Man were connected into this wider world even if not all of the ceremonial and cosmological features of some neighbouring regions were adopted here. The fact that Grooved Ware did not replace Ronaldsway Jars also illustrates the partial integration of that widespread tradition into existing local later 4th millennium pottery and burial traditions.

\section{CONCLUSION}

This research has filled in a substantial gap in the history of mortuary practices in the Neolithic of the Isle of Man. Comparisons with parallel practices in Britain and Ireland also suggest that the oft-cited narrative of an isolated Isle of Man in the 'Ronaldsway period' needs rethinking (Crellin 2019). While there are certainly distinctive local forms of artefacts, it is questionable that there was an impermeable, homogeneous and unchanging 'Ronaldsway Culture', and changes in mortuary practices resonated with other regions much more strongly than previously realised. In the Middle Neolithic this can be observed in the use of cremation and cists, while during the Late Neolithic 
Grooved Ware pottery and designs were incorporated into existing traditions of practice just as Ronaldsway pottery had been centuries before. We are now starting to glimpse historical change within the entire Neolithic on the Isle of Man and, in the process, we are moving beyond the homogenising effect of culture historic terms. Post-excavation analysis of pits containing fragments of Ronaldsway pottery at Cronk Guckley, Berk Farm, some of which were covered by an Early Bronze Age burial mound, may add further detail to this picture in the next few years.

Acknowledgements We would like to thank Allison Fox at Manx National Heritage for providing access to the Manx Museum collections, Culture Vannin for funding the osteological analyses, Manx National Heritage for funding the radiocarbon dating, and Rob Clynes at the Mapping Unit, Department of Infrastructure, Isle of Man for providing LiDAR map data. Thanks to Eleanor Harrison for sharing her $\mathrm{PhD}$ data on single burials in Britain and Ireland, and Ollie Harris and the anonymous peer reviewers for invaluable comments on a draft of the article.

\section{SUPPLEMENTARY MATERIAL}

To view supplementary material for this article, please visit https://doi.org/10.1017/ppr.2021.12

\section{NOTES}

${ }^{1}$ The rough chronology for subdivisions of the Neolithic period in Britain and Ireland used in this article are as follows, but regional variations can span c. 100-150 years: Earliest Neolithic: 40003850 cal BC; Early Neolithic: 3850-3500/3400 cal BC; Middle Neolithic: 3500/3400-3000 cal BC; Late Neolithic: 3000-2500 cal BC; Chalcolithic or Terminal Neolithic: 2500-2200 cal BC.

${ }^{2}$ Also referred to with the anglicised spelling Mull Hill.

${ }^{3}$ The authors were uncertain if further traces of paint will be revealed on other vessels, whether all vessels were painted, or whether cleaning techniques might well have destroyed paint on other examples (Darvill \& Andrews 2014, 536).

${ }^{4}$ The footprint of the Ronaldsway house could potentially be taken as a version of square houses associated with Grooved Ware in southern Britain, Orkney and parts of Ireland, but only by selectively ignoring the southern part of the site plan in Bruce et al. (1947).

${ }^{5}$ Unfortunately, no human remains are available for analysis from the chambered tombs on the island with the exception of those from Ballaharra. These could not be found in 2016 but are now known to be in the Duckworth Museum, Cambridge.

${ }^{6}$ We cannot produce a reliable Bayesian model for the use of these cists as there is no stratigraphic relationship between them and only cist VI from Killeaba is situated in a stratigraphic relationship with other dated material (see below).
${ }^{7}$ The next oldest date directly associated with a Ronaldsway vessel is 3333-2910 cal BC (Burrow \& Darvill 1997, 413) and comes from carbonised residues on a sherd from a suspected occupation site at Ballacottier.

${ }^{8}$ We cannot produce a reliable Bayesian model for the use of Ronaldsway Jars as none has been found in a context providing any stratigraphic relationships with other securely dated material. Some of the dates are from cremated bone while others are from carbonised residues on sherds, and the error range for some of the latter dates is high.

${ }^{9}$ It is of course possible that there are as-yet undated cremation deposits (and potentially unburnt remains) that were placed in cists in the Middle Neolithic in Britain and Ireland; only further dating programmes will tell.

\section{BIBLIOGRAPHY}

Anderson-Whymark, H. and Thomas, J. (eds). 2012. Regional Perspectives on Neolithic Pit Deposition: Beyond the mundane. Oxford: Neolithic Studies Group Seminar Papers 12

Appleby, J. 2013. Temporality and the transition to cremation in the late third millennium to mid second millennium $\mathrm{BC}$ in Britain. Cambridge Archaeological Journal 23(1), 83-97

Ard, V. \& Darvill, T. 2015. Revisiting old friends: The production, distribution and use of Peterborough Ware in Britain. Oxford Journal of Archaeology 34(1), 1-31

Armit, I., Shapland, F., Montgomery, J. \& Beaumont, J. 2015. Difference in death? A lost Neolithic inhumation cemetery with Britain's earliest case of rickets, at Balevullin, western Scotland. Proceedings of the Prehistoric Society 81, 199-214

Barrs, K. 2010. Manx Stone Axehead Project. Unpublished MA dissertation, University of Liverpool

Bayliss, A., Marshall, P., Richards, C. \& Whittle, A. 2017. Islands of history: The Late Neolithic timescape of Orkney. Antiquity 91, 1171-88

Bersu, G. 1947. A cemetery of the Ronaldsway Culture at Ballateare, Jurby, Isle of Man. Proceedings of the Prehistoric Society 8, 161-9

Brace, S., Diekmann, Y., Booth, T.J., Dorp, L. van, Faltyskova, Z., Rohland, N., Mallick, S., Olalde, I., Ferry, M., Michel, M., Oppenheimer, J., Broomandkhoshbacht, N., Stewardson, K., Martiniano, R., Walsh, S., Kayser, M., Charlton, S., Hellenthal, G., Armit, I., Schulting, R., Craig, O.E., Sheridan, A., Parker Pearson, M., Stringer, C., Reich, D., Thomas, M.G. \& Barnes, I. 2019. Ancient genomes indicate population replacement in Early Neolithic Britain. Nature Ecology and Evolution 3, 765-7

Bradley, R., Watson, A. \& Style, P. 2019. After the axes? The rock art at Copt Howe, north-west England, and the Neolithic sequence at Great Langdale. Proceedings of the Prehistoric Society 85, 177-92

Brindley, A.L., Lanting, J.N. \& Mook, W.G. 1983. Radiocarbon dates from the Neolithic burials at 


\section{Fowler et al. CHANGE \& DIVERSITY, NEOLITHIC MORTUARY PRACTICES, ISLE OF MAN}

Ballintruer More, Co. Wicklow and Ardcrony, Co. Tipperary. Journal of Irish Archaeology 1, 1-9

Brindley, A. \& Lanting, J.N. 1989-90. Radiocarbon dates for Neolithic single burials. Journal of Irish Archaeology 5, 1-7

Bronk Ramsey, C. 2009. Bayesian analysis of radiocarbon dates. Radiocarbon, 51(1), 337-60

Bruce, J.R., Megaw, E.M. \& Megaw, B.R.S. 1947. A Neolithic site at Ronaldsway, Isle of Man. Proceedings of the Prehistoric Society 12, 139-60

Brück, J. 2019. Personifying Prehistory: Relational ontologies in Bronze Age Britain and Ireland. Oxford: Oxford University Press

Burrow, S. 1997. The Neolithic Culture of the Isle of Man: A study of the sites and pottery. Oxford: British Archaeological Report 263

Burrow, S. 2010. Bryn Celli Ddu passage tomb, Anglesey: Alignment, construction, date, and ritual. Proceedings of the Prehistoric Society 76, 249-70

Burrow, S. 2017. Pottery report: King Orry's Grave north-east chamber. In Lynch \& Davey (eds) 2017, $131-2$

Burrow, S. \& Darvill, T. 1997. AMS dating of the Manx Ronaldsway Neolithic. Antiquity 71, 412-19

Carlin, N. 2017. Getting into the groove: Exploring the relationship between Grooved Ware and developed passage tombs in Ireland c. 3000-2700 cal BC. Proceedings of the Prehistoric Society 83, 155-88

Cooney, G. 2000. Landscapes of Neolithic Ireland. London: Routledge

Crellin, R.J. 2014. Changing Times: The emergence of a Bronze Age on the Isle of Man. Unpublished $\mathrm{PhD}$ Thesis, Newcastle University

Crellin, R.J. 2015. Tracing change at Killeaba. Isle of Man Studies 13, 29-44

Crellin, R.J. 2017. Changing assemblages: Tracing vibrant matter in burial assemblages. Cambridge Archaeological Journal 27(1), 111-25

Crellin, R.J. 2019. The emergence of a Bronze Age on the Isle of Man. In D. Brandherm (ed.), Aspects of the Bronze Age in the Atlantic Archipelago and Beyond. Proceedings from the Belfast Bronze Age Forum 9-10 November 2013, 13-34. Berlin: Archaeologia Atlantica - Monographiae III

Crellin, R.J. \& Fowler, C. 2017. Cronk Guckley, Berk Farm: 2017 Excavation Interim Report. Unpublished report: https://roundmounds.wordpress.com/category/ 2017-interim-site-report/

Crellin, R.J. \& Fowler, C. 2018. Cronk Guckley, Berk Farm: 2018 Excavation Interim Report. Unpublished report: https://roundmounds.wordpress.com/category/ 2018-interim-site-report/

Crellin, R.J. \& Fowler, C. 2020. Cronk Guckley, Berk Farm: 2019 Excavation Interim Report. Unpublished report: https://roundmounds.wordpress.com/category/ 2019-interim-site-report/

Cubbon, A.M. n.d. Untitled: Unpublished manuscript reporting on the 1959 excavation at Crosby Farm.
Douglas: Manx National Heritage Archives (MNH NMHER 381)

Cubbon, A.M. 1978. Excavation at Killeaba, Ramsey, Isle of Man. Proceedings of the Prehistoric Society 44, 69-95

Cummings, V. 2017. The Neolithic of Britain and Ireland. London: Routledge.

Cummings, V. \& Robinson, G. 2015. The life and times of a chambered tomb: The results of survey and excavation at Blasthill chambered tomb, Kintyre, Western Scotland. Archaeological Journal 172(1), 1-29

Darvill, T. 2000. Neolithic Mann in context. In A. Ritchie (ed.), Neolithic Orkney in its European Context, 371385. Cambridge: McDonald Institute Monographs

Darvill, T. (ed.). 1996. Billown Neolithic Landscape Project, Isle of Man: 1995 research report 1. Bournemouth \& Douglas: Bournemouth University Press

Darvill, T. (ed.). 1997. Billown Neolithic Landscape Project, Isle of Man, Research Report 3: 1996. Bournemouth \& Douglas: Bournemouth University Press

Darvill, T. 2012. Sounds from the underground: Neolithic ritual pits and pit-clusters. In Anderson-Whymark \& Thomas (eds) 2012, 30-42

Darvill, T. \& Andrews, K. 2014. Polychrome pottery from the Later Neolithic of the Isle of Man. Cambridge Archaeological Journal 24(3), 531-41

Denston, C.B. \& Allen, D. 2017. The cremated and unburnt bones from Ballaharra. In Lynch \& Davey (eds) 2017, 171-3

Fowler, C. 2001. Personhood and social relations in the British Neolithic, with a study from the Isle of Man. Journal of Material Culture 6(2), 137-63

Fowler, C. 2004. In touch with the past? Monuments, bodies and the sacred in the Manx Neolithic and beyond. In V. Cummings \& C. Fowler (eds), The Neolithic of the Irish Sea: Materiality and traditions of practice, 91-102. Oxford: Oxbow Books

Fowler, C. 2008. Fractal bodies in the past and present. In D. Boriç \& J. Robb (eds), Past Bodies: Body-centered research in archaeology, 47-57. Oxford: Oxbow Books

Fowler, C. 2013. The Emergent Past: A relational realist archaeology of Early Bronze Age mortuary practices. Oxford: Oxford University Press

Gamble, M. 2017a. Osteological report on the human remains from Ballafayle. Unpublished report from the Round Mounds of the Isle of Man project, held at the Manx Museum, Isle of Man

Gamble, M. 2017b. Osteological report on the human remains from Cronk y Voddee. Unpublished report from the Round Mounds of the Isle of Man project, held at the Manx Museum, Isle of Man

Gamble, M. 2017c. Osteological report on the human remains from Kimmeragh. Unpublished report from the Round Mounds of the Isle of Man project, held at the Manx Museum, Isle of Man

Gamble, M. 2017d. Osteological report on the human remains from Bishops Demesne. Unpublished report from the Round Mounds of the Isle of Man project, held at the Manx Museum, Isle of Man 
Gamble, M. 2017e. Osteological report on the human remains from Cronk Coar. Unpublished report from the Round Mounds of the Isle of Man project, held at the Manx Museum, Isle of Man

Gamble, M. 2017f. Osteological report on the buman remains from Ballateare. Unpublished report from the Round Mounds of the Isle of Man project, held at the Manx Museum, Isle of Man

Gamble, M. 2017g. Osteological report on the human remains from Killeaba. Unpublished report from the Round Mounds of the Isle of Man project, held at the Manx Museum, Isle of Man

Garrad, L.S. 1984a. Rescue excavations at Ballacottier. Proceedings of the Isle of Man Natural History \& Antiquarian Society 9, 159-62

Garrad, L.S. 1984b. Rescue excavations at Ballavarry. Proceedings of the Isle of Man Natural History \& Antiquarian Society 9, 162-8

Garrad, L. 1987. A Ronaldsway Neolithic site on West Kimmeragh, Bride, Isle of Man. Proceedings of the Isle of Man Natural History \& Antiquarian Society 12, 421-6

Gibson, A. \& Bayliss, A. 2009. Recent research at Duggleby Howe, North Yorkshire. Archaeological Journal 166, $38-78$

Harris, O.J.T., Cobb, H, Gray, H. \& Richardson, P. 2014. New radiocarbon dates from Cladh Aindreis chambered tomb, Ardnamurchan. PAST 76, 5-7

Harrison, S.N. 1909. Excavation at Ballaterson Cronk, Maughold. Proceedings of the Isle of Man Natural History \& Antiquarian Society 1, 184

Henshall, A. 2017a. The artefacts from the tombs. In Lynch \& Davey (eds) 2017, 94-106

Henshall, A. 2017b. Catalogue. In Lynch \& Davey (eds) 2017, 13-93

Herity, M. 1982. Irish decorated Neolithic pottery. Proceedings of the Royal Irish Academy 82C, 247-404

Higgins, D.A. \& Davey, P.J. 2017. Appendix 2: Excavations by Sheila Cregeen at Ballaharra, German, 1969-1983. In Lynch \& Davey (eds) 2017, 135-54

Jay, M., Montgomery, J., Parker Pearson, M. \& Sheridan, A. 2019. Appendix 1: The pre-2500 BC individuals. In M. Parker Pearson, A. Sheridan, M., Jay, A. Chamberlain, M. Richards and J. Evans (eds), The Beaker People: Isotopes, mobility and diet in prehistoric Britain, 492-500. Oxford: Prehistoric Society Research Paper 7

Jones, A.M. 2017. Preserved in the Peat: An extraordinary Bronze Age burial on Whitehorse Hill, Dartmoor, and its wider context. Oxford: Oxbow Books

Jones, A., Diaz-Guardamino, M. \& Crellin, R.J. 2016. From artefact biographies to 'multiple objects': A new analysis of the decorated plaques of the Irish Sea Region. Norwegian Archaeological Review 49(2), 113-33

Jones, A. M., Diaz-Guardamino Uribe, M., Gibson, A. \& Cox, S. 2017. The Garboldisham macehead: its manufacture, date, archaeological context and significance. Proceedings of the Prehistoric Society 83, 383-94
Kermode, P.M.C. 1902. Report of the archaeological section. Yn Lioar Manninagh 4, 372-5

Kewley, K. 2016. The Manx Stone Axe-head Project: Interconnection or isolation? The evidence from stone axeheads frof the Manx Neolithic in its Irish Sea context. Unpublished $\mathrm{PhD}$ thesis, University of Liverpool

Kilbride-Jones, H., Morant, G. \& Stelfox, A. 1939. The excavation of a composite tumulus at Drimnagh, Co. Dublin. Journal of the Royal Society of Antiquaries of Ireland 9(4), 190-220

Kytmannow, 2008. Portal Tombs in the Landscape: The chronology, morphology and landscape setting of the portal tombs of Ireland, Wales and Cornwall. Oxford: British Archaeological Report 455

Lewis, J. \& Terry, J. 2004. The excavation of an Early Bronze Age cemetery at Holly Road, Leven, Fife. Tayside and Fife Archaeological Journal 10, 23-53

Loveday, R. \& Barclay, A. 2010. One of the most interesting barrows ever examined - Liffs Low revisited. In J. Leary, T. Darvill and D. Field (eds), Round Mounds and Monumentality in the British Neolithic, 108-129. Oxford: Neolithic Studies Group Seminar Papers 10

Lynch, F. 2017. General summary. In Lynch \& Davey (eds) 2017, 107-12

Lynch, F. \& Davey, P. (eds). 2017. The Chambered Tombs of the Isle of Man: A study by Audrey Henshall, 1969-78. Oxford: Archaeopress.

Masters, L. 1973. The Lochhill long cairn. Antiquity 47, 96-100

Megaw, B.R.S. 2017. Appendix 1: The excavation of King Orry's Grave (North East), 1953. In Lynch \& Davey (eds) 2017, 119-31

Noble, G. 2006. Neolithic Scotland: Timber, stone, earth and fire. Edinburgh: Edinburgh University Press.

Noble, G. \& Brophy, K. 2017. Cremation practices and the creation of monument complexes: The Neolithic cremation cemetery at Forteviot, Strathearn, Perth \& Kinross, Scotland. Proceedings of the Prehistoric Society 83, 213-47

O'Sullivan, M. 2005. Duma na nGiall. The Mound of the Hostages, Tara. Dublin: University College Dublin School of Archaeology/Wordwell

O'Sullivan, M. \& Downey, L. 2019. Individual burial in the Irish Neolithic. Archaeology Ireland 33(3), 48-51

Piggott, S. 1954. The Neolithic Cultures of the British Isles. Cambridge: Cambridge University Press

Powell, A.B., Barclay, A.J., Mepham, J. \& Stevens, C.J. 2015. Imperial College Sports Ground and RMC Land, Harlington: The development of prehistoric and later communities in the Colne Valley and on the Heathrow Terrace. Salisbury: Wessex Archaeology

Raftery, J. 1973. A Neolithic burial mound at Ballintruer More, Co. Wicklow. Journal of the Royal Society of Antiquaries of Ireland 103, 214-19

Rainbird, P. \& Lichtenstein, L. 2018. A Middle Neolithic ring ditch and settlement at King Alfred Way, Newton Poppleford. Proceedings of the Devon Archaeological Society 76, 29-56 


\section{Fowler et al. CHANGE \& DIVERSITY, NEOLITHIC MORTUARY PRACTICES, ISLE OF MAN}

Reimer, P., Austin, W., Bard, E., Bayliss, A., Blackwell, P., Bronk Ramsey, C., Butzin, M., Cheng, H., Edwards, R., Friedrich, M., Grootes, P., Guilderson, T., Hajdas, I., Heaton, T., Hogg, A., Hughen, K., Kromer, B., Manning, S., Muscheler, R., Palmer, J., Pearson, C., van der Plicht, J., Reimer, R., Richards, D., Scott, E., Southon, J., Turney, C., Wacker, L., Adolphi, F., Büntgen, U., Capano, M., Fahrni, S., Fogtmann-Schulz, A., Friedrich, R., Köhler, P., Kudsk, S., Miyake, F., Olsen, J., Reinig, F., Sakamoto, M., Sookdeo, A. \& Talamo, S. 2020. The IntCal20 Northern Hemisphere radiocarbon age calibration curve $(0-55$ cal $\mathrm{kBP})$. Radiocarbon 62, 725-57

Roberts, D., Barclay, A., Bishop, B., Bronk-Ramsey, C., Campbell, G., Canti, M., Dobie, J., Dunbar, E., Dunne, J., Evershed, R.P., Forward, A., Last, J., Lamb, S., Linford, S., Linford, P., Linscott, B., Madgwick, R., Marshall, P., Mays, S., McParland, H., Payne, A., Pelling, R., Pike, A., Price, K., Quinn, P., Radini, A., Reimer, P., Russell, M., Seager Smith, R., Soutar, S., Speller, C., Vallender, J., Valdez-Tullett, A., Heekeren, V. van \& Worley, F. 2020. Middle Neolithic pits and a burial at West Amesbury, Wiltshire. Archaeological Journal 177(2), 167-213. DOI: 10.1080/00665983.2020.1758495

Ryan, M.F. 1973. The excavation of a Neolithic burial mound at Jerpoint West, Co. Kilkenny. Proceedings of the Royal Irish Academy 73C, 107-27

Ryan, M.F. 1981. Poulawack, Co. Claire: The affinities of the central burial structure. In D. Ó Corráin (ed.), Irish Antiquity, 134-46. Cork: Tower Books

Schulting, R., Murphy, E., Jones, C \& Warren, G. 2011. New dates from the north and a proposed chronology for Irish court tombs. Proceedings of the Irish Royal Academy 112, 1-60

Sheridan, J.A. 1995. Irish Neolithic pottery: The story in 1995. In I. Kinnes \& G. Varndell (eds), 'Unbaked urns of rudely shape'. Essays on British and Irish pottery for Ian Longworth, 3-22. Oxford: Oxbow Monograph 55

Sheridan, A. \& Schulting, R. 2020. Making sense of Scottish Neolithic funerary monuments: tracing trajectories and understanding their rationale, in A.B. Gebauer, L. Sørensen, A. Teather \& A. Carlos Valera (eds) Monumentalising Life in the Neolithic: narratives of change and continuity, 195-216. Oxford: Oxbow.

Smyth, J. 2014. Settlement in the Irish Neolithic: New discoveries on the edge of Europe. Oxford: Prehistoric Society Research Paper 6

Snoeck, C., Brock, F. \& Schulting, R.J. 2014. Carbon exchanges between bone apatite and fuels during cremation: impact on radiocarbon dates. Radiocarbon 56(2), 591-602

Tellier, G. 2018. Neolithic and Bronze Age Funerary Practices in Wales, 3600-1200 BC. Oxford: British Archaeological Report 624

Thomas, J. 2010. The return of the Rinyo-Clacton folk? The cultural significance of the Grooved Ware complex in later Neolithic Britain. Cambridge Archaeological Journal 20, $1-15$

Topping, P. 1992. The Penrith henges: A survey by the Royal Commission on the Historical Monuments of England. Proceedings of the Prehistoric Society 58, 249-64

Whittle, A., Healy, F. \& Bayliss, A. (eds). 2011. Gathering Time: Dating the Early Neolithic enclosures of Southern Britain and Ireland. Oxford: Oxbow Books.

Willis, C. 2019. Stonehenge and Middle to Late Neolithic Cremation Rites in Mainland Britain (c. 3500-2500 $B C)$. Unpublished $\mathrm{PhD}$ thesis, University College London Willis, C., Marshall, P., McKinley, J.I., Pitts, M., Pollard, J., Richards, C., Thomas, J., Waldron., T., Welham, K. \& Parker Pearson, M. 2016. The dead of Stonehenge. Antiquity 90, 337-56

\section{RÉSUMÉ}

Changement et diversité dans les pratiques mortuaires de l'île de Man Néolithique, de Chris Fowler, Rachel J. Crellin et Michelle Gamble.

Tandis que les tombes à chambre du début du Néolithique de l'île de Man sont bien connues et le Néolithique tardif a été bien clairement défini en faisant référence à une suite d'artifacts distincts, le Néolithique moyen est très peu connu. Cet article rend compte de 17 nouvelles datatations au $\mathrm{C}^{14}$ de restes humains incinerés de l'île de Man. Ils ont identifié cinq inhumations comme étant du Néolithique moyen et indiquent de nouvelles séquences d'activité dans des cimetières qui commencèrent au milieu du Néolithique. Chacun de ces sites est examiné en détail. Ces dates nous ont aussi incité á reconsidérer la potterie de Ronaldsway et l'intégration de motifs de la poterie des vases cordés dans les pratiques du début de 3ème millenaire. L'article se termine par une évaluation des effets changeants des pratiques mortuaires à travers le Néolithique sur l'île de Man et une discussion des connectiuons avec le Néolithique moyen et tardif en Irlande et en Grande Bretagne. 
THE PREHISTORIC SOCIETY

\section{ZUSAMMENFASSUNG}

Wandel und Diversität in neolithischen Bestattungspraktiken auf der Isle of Man, von Chris Fowler, Rachel J. Crellin und Michelle Gamble

Während die Ganggräber des Frühneolithikums von der Isle of Man gut gekannt sind und auch das Spätneolithikum anhand einer ausgeprägten Reihe von Artefakten klar definiert wurde, ist wenig über das Mittelneolithikum bekannt. Dieser Artikel legt 17 neue Radiokarbondaten aus dem Neolithikum von Leichenbrand von der Isle of Man vor. Durch sie werden fünf Bestattungen in Steinkisten in das Mittelneolithikum datiert und neue Abfolgen von Handlungen an den Bestattungsplätzen angezeigt, die im im Mittelneolithikum beginnen. Jeder dieser Fundorte wird detailliert untersucht. Die Daten regen auch dazu an, die Entwicklung der Ronaldsway-Keramik ebenso zu überdenken wie die Integration der Keramik und Motivik der Grooved Ware in Praktiken des frühen 3. Jahrtausends auf der Insel. Der Beitrag endet mit einer Betrachtung der sich verändernden Auswirkungen der Bestattungspraktiken während des Neolithikums auf der Isle of Man und einer Diskussion der Verbindungen zum Mittel- und Spätneolithikum in Irland und Großbritannien.

\section{RESUMEN}

Cambio y diversidad en las prácticas funerarias neoliticas en la Isla de Man, por Chris Fowler, Rachel J. Crellin y Michelle Gamble

A pesar de que las tumbas con cámara del Neolítico inicial son bien conocidas en la Isla de Man y de que el Neolítico final ha sido claramente definido a partir de los conjuntos materiales, se sabe poco acerca del Neolítico medio. En este artículo se presentan 17 nuevas dataciones radiocarbónicas de restos humanos cremados de la Isla de Man. Implican la documentación de cinco enterramientos en cista del Neolítico medio e indican nuevas secuencias de actividad en los cementerios que comienzan en el Neolítico medio. Se examina en detalle cada uno de estos sitios. Estas dataciones también estimulan una reconsideración del desarrollo de la cerámica Ronaldsway y la integración de la cerámica Grooved Ware y sus motivos en el marco de las actividades de la isla durante el III milenio. Este artículo finaliza con una reflexión de las modificaciones de las prácticas funerarias a lo largo del Neolítico en la Isla de Man y una discusión de las conexiones durante el Neolítico medio y final en Irlanda y Gran Bretaña. 